University of Michigan Law School University of Michigan Law School Scholarship Repository

1987

\title{
Loss of Innocence: Eyewitness Identification and Proof of Guilt
}

Samuel R. Gross

University of Michigan Law School, srgross@umich.edu

Available at: https://repository.law.umich.edu/articles/557

Follow this and additional works at: https://repository.law.umich.edu/articles

Part of the Criminal Procedure Commons, Evidence Commons, Law Enforcement and Corrections Commons, and the Supreme Court of the United States Commons

\section{Recommended Citation}

Gross, Samuel R. "Loss of Innocence: Eyewitness Identification and Proof of Guilt." J. Legal Stud. 16 (1987): 395-453.

This Article is brought to you for free and open access by the Faculty Scholarship at University of Michigan Law School Scholarship Repository. It has been accepted for inclusion in Articles by an authorized administrator of University of Michigan Law School Scholarship Repository. For more information, please contact mlaw.repository@umich.edu. 


\title{
LOSS OF INNOCENCE: EYEWITNESS IDENTIFICATION AND PROOF OF GUILT
}

\author{
SAMUEL R. GROSS*
}

\section{INTRODUCTION}

$\mathrm{I}_{\mathrm{r}}$ $T$ is no news that eyewitness identification in criminal cases is a problem; it is an old and famous problem. Judges and lawyers have long known that the identification of strangers is a chancy matter, ${ }^{1}$ and nearly a century of psychological research has confirmed this skeptical view. ${ }^{2}$ In 1967 the Supreme Court attempted to mitigate the problem by regulating the use of eyewitness identification evidence in criminal trials; ${ }^{3}$ since then

* Acting Associate Professor, Stanford Law School. This paper has benefited from research assistance by Mark Yeager, Kenneth Diamond, Patrick Adair, and Yonkel Goldstein and from comments on earlier drafts by Barbara Babcock, John Kaplan, Elizabeth Loftus, Robert Mnookin, and, especially, Phoebe Ellsworth. This research was supported by the Stanford Legal Research Fund, made possible by a bequest from the Estate of Ira S. Lillick and by gifts from Roderick E. and Carla A. Hills and other friends of Stanford Law School.

' See, for example, Report of Committee of Inquiry into Case of Adolph Beck (London 1904) 62 Parl. Papers (1905), Sec. 2315; Felix Frankfurter, The Case of Sacco and Vanzetti 30 (1927); Edwin M. Borchard, Convicting the Innocent, at xiii (1932); Judicial Council of the State of New York, Fourteenth Annual Report of the Judicial Council of the State of New York 229-68 (1948); Patrick M. Wall, Eyewitness Identification in Criminal Cases (1965); Wade v. United States, 388 U.S. 219, 229 (1967) (quoting Wall, supra); Patrick Devlin et al., Report to the Secretary of State for the Home Department of the Departmental Committee on Evidence of Identification in Criminal Cases (1976).

2 See, for example, Hugo Munsterberg, On the Witness Stand: Essays on Psychology and Crime 39-69 (1908); Felice J. Levine \& June L. Tapp, The Psychology of Criminal Identification: The Gap from Wade to Kirby, 121 U. Pa. L. Rev. 1079 (1973); A. Daniel Yarmey, The Psychology of Eyewitness Testimony (1979); Elizabeth F. Loftus, Eyewitness Testimony (1979); Special Issue, 4 Law \& Hum. Behav. (No. 4, 1980); Gary L. Wells \& Donna M. Murray, What Can Psychology Say about the Neil v. Biggers Criteria for Judging Eyewitness Accuracy? 68 J. Applied Psych. 347 (1983); Gary L. Wells \& Elizabeth F. Loftus, Eyewitness Testimony (1984).

3 Wade v. United States, 388 U.S. 218 (1967); Gilbert v. California, 388 U.S. 263 (1967); Stovall v. Denno, 388 U.S. 293 (1967); see also Simmons v. United States, 390 U.S. 377 (1968).

[Journal of Legal Studies, vol. XVI (June 1987)]

(C) 1987 by The University of Chicago. All rights reserved. 0047-2530/87/1602-0003\$01.50 
it has retreated part way from that effort. ${ }^{4}$ Legal scholars have written a small library of books and articles on this problem, the courts' response to it, and various proposed solutions. ${ }^{5}$ But all this extensive attention has focused on one side of the problem of eyewitness identification: Why are mistakes so common, and how can they be prevented? I start from a different question: Why are eyewitness misidentifications so rare?

This question requires some specification. I am not concerned with all misidentifications but only with those that have the most serious consequences-the conviction of innocent people. Nor do I suggest that such miscarriages of justice are less frequent than they ought to be, and I do not disagree with the general consensus on the importance of this problem: as far as anyone can tell, eyewitness misidentification is by far the most frequent cause of erroneous convictions. But while convictions based on eyewitness errors may be more frequent than are other types of erroneous convictions, in absolute terms they are rare. And that presents a paradox: eyewitness identification is (1) a notoriously unreliable type of evidence, (2) the basis of numerous guilty verdicts, and yet (3) the source of only a small number of wrongful convictions. Why?

At the outset I should say a few words about two assumptions on which this paradox is based. The first is that misidentifications by eyewitnesses are (at least) reasonably likely. There is little doubt that this is so, although the magnitude of the problem is difficult, perhaps impossible to estimate. Eyewitness unreliability is the unmistakable conclusion of a vast quantity of psychological research, and lawyers seem to agree. Virtually every legal commentator who has addressed the issue has concurred with Justice Frankfurter that " $[t]$ he identification of strangers is proverbially untrustworthy. The hazards of such testimony are established by a formidable number of instances in the records of English and American trials." 6

It follows from this premise that eyewitness identification evidence should lead to numerous erroneous convictions. If misidentifications are reasonably likely, then errors will occur in a substantial proportion of those cases in which proof of identity depends on eyewitness testimony,

${ }^{4}$ Kirby v. Illinois, 406 U.S. 682 (1972); Neil v. Biggers, 409 U.S. 188 (1972); United States v. Ash, 413 U.S. 300 (1973); Manson v. Brathwaite, 432 U.S. 682 (1977).

5 See, for example, George Harris, A Treatise on the Law of Identification (1892); Harrison H. Wilder \& Bert Wentworth, Personal Identification (1918); Wall, supra note 1; William E. Ringel, Identification and Police Lineups (1968); Nathan R. Sobel, Eye-Witness Identification (1972); and Lawrence Taylor, Eyewitness Identification (1982). There is little point in citing the numerous law review articles on eyewitness identification. Useful bibliographies may be found in Sobel, supra; and Taylor, supra.

${ }^{6}$ Frankfurter, supra note 1 , at 30. 
and such cases are common. Identity is an essential element of any criminal conviction, although it is not usually in dispute. Many defendants are caught red-handed, many others admit their guilt, some are identified by highly reliable physical evidence (such as fingerprints), and some are identified by witnesses who know them well and are unlikely to err. Nonetheless, identifications by strangers are a common form of evidence in criminal trials, and there are many cases-typically convictions for violent crimes-in which the only formal evidence of identity is eyewitness testimony. Considering the enormous volume of such cases, the untrustworthiness of eyewitness identifications should lead us to expect hundreds, perhaps thousands, of erroneous convictions each year across the United States. ${ }^{7}$

My second assumption is that far fewer convictions are caused by misidentifications than the experimental evidence would lead us to expect. John Kaplan, who posed this problem several years ago, asserts that, "considering the large number of subsequent confessions to previously unsolved crimes and the volume of new evidence that constantly turns up, the number of cases where someone already convicted is later shown to be innocent is far less than one would expect." note that the evidence available to support this assertion is weak. It is true that few misidentifications come to public attention, but it is possible that

\footnotetext{
7 There are no actual figures on the number of convictions based on eyewitness identifications, but statistics on some of the underlying crimes suggest the general magnitude of the issue. In 1980 over 10,000 defendants were convicted of rape, robbery, or aggravated assault in Superior Courts in California. See California Dep't Justice, Bur. Criminal Statistics, Crime and Delinquency in California, 1980, at 45 (1981). These are crimes that are committed mainly by strangers. U.S. Dep't Justice, Bur. Justice Statistics, Sourcebook of Criminal Justice Statistics, 1982, at 324-25 (1982). If as few as one in 100 of these convictions were based on misidentifications, there would have been some 100 miscarriages of justice in California in that one year in this category of convictions alone, which does not include a large number of convictions of juveniles-California Dep't Justice, supra, at 30-a larger number of convictions in lower courts (id. at 45), or any convictions for any other crimes. Devlin et al., supra note 1, contains partial data on this issue for England and Wales. It reports that in 1973, 697 defendants were convicted in those jurisdictions after being identified at police lineups. If as few as $\mathbf{1 0}$ percent of these identifications were erroneous, there would have been about seventy errors among these convictions and larger numbers in succeeding years, plus an undetermined number of errors in eyewitness identification cases in which lineups were not conducted. Other things being equal, one would expect the comparable numbers in the United States to be roughly ten to twenty times as large. This last estimate is based on a comparison of general criminal statistics in the two countries. For example, in 1980 there were some 3,500 convictions for robbery in England and Wales, including some convictions of juveniles-Home Office, Criminal Statistics, England and Wales 1982, at 182 (1983) - while in California, a state that includes about 10 percent of the population of the United States, there were some 5,300 robbery convictions of adults only. See California Dep't Justice, supra note 7, at 45.

8 John Kaplan, Foreword, in Loftus, supra note 2, at viii.
} 
many cases that are discovered receive little or no publicity, and it is certain that many others (perhaps the great majority) are never discovered at all. Even so, I believe that the gap between the expected number of erroneous convictions based on misidentification and the reported number is so great that the expected rate must be much too high. This premise, however, must be recognized as a hypothesis rather than as a fact.

Assuming that this hypothesis is correct, how then have we been misled? The answer is that psychologists and lawyers alike have focused on eyewitness identifications in isolation from the context in which they occur. Psychologists have been interested in the problems of perception and memory that are posed by eyewitness evidence, not in criminal procedure in general, and lawyers have been concerned with the formal aspects of criminal adjudication (of which eyewitness identification is an important part) and not in the informal process of investigation by which the identity of criminals is usually determined. As a result, two things have been overlooked. First, the process of identifying criminals is more accurate than it seems, and, second, some of the major causes of the errors that do occur have never been addressed.

\section{The Problem of Eyewitness Identification}

This is not the place for an extended review of the psychological research on eyewitness identification, but a précis of the major findings in the area will be useful.

Consider a common situation. A woman sees a strange man rob a grocery store at which she is a customer. This encounter is the basis of any identification she might later make. Several factors have been shown to affect the quality of the witness's perception at this initial point. Experimental studies confirm the intuitive notion that the longer the stranger is seen the easier he will be to identify, ${ }^{9}$ but they add a wrinkle: eyewitnesses systematically overestimate the duration of such an event. ${ }^{10}$ Similarly, the research is consistent with our common knowledge that if the witness is distracted by other stimuli she will be less able to identify the

9 Kenneth R. Laughrey, Judith F. Alexander, \& Alan B. Lane, Recognition of Human Faces: Effects of Target Exposure Time, Target Position, Pose Position, and Type of Photograph, 55 J. Applied Psych. 477 (1971).

${ }^{10}$ See, for example, Robert Buckhout et al., Determinants of Eyewitness Performance on a Lineup, 4 Bull. Psychonomic Soc'y 191 (1974); H. R. Shiffman \& Douglas J. Bobko, Effects of Stimulus Complexity on Brief Temporal Events, 103 J. Experimental Psych. 156 (1974); James Marshall, Law and Psychology in Conflict (1966); and Munsterberg, supra note 2. 
robber than if she could focus her attention on his face, ${ }^{11}$ but again there is an added complexity: attention to the details of the features of the face is less useful than an attempt to reach a general judgment-apparently almost any general judgment-about the person who is seen. ${ }^{12}$ In general, witnesses who are subject to high stress are less accurate than those who are subject to moderate stress, and this factor appears to affect eyewitness identifications. ${ }^{13}$ In addition, several studies confirm the common belief that interracial identifications are more difficult than are intraracial ones. $^{14}$

The image that the witness has formed in the original encounter, however sketchy or complete, must be retained in her memory until an identification can be attempted. People generally believe that their memories fade over time, and psychological research confirms that belief. Some recent studies suggest that the accuracy of identifications of strange faces is relatively stable over periods up to several weeks or a few months after the target person has been seen, but that may simply reflect the fact that the most dramatic decline in accuracy occurs within the first few hours. ${ }^{15}$ But while time itself may not do much damage, what happens in that time may; the witness's memory can be altered during this period of retention by new information that she obtains from the police, from news reports, or from other sources. ${ }^{16}$ Finally, the retained memory must be

1 Hadyn D. Ellis \& Donald F. Christie, Some Practical Problems of Face Recall: Pictures vs. Words (paper presented at the Twenty-second International Congress of Psychology, Leipzig 1980), in Wells \& Loftus, supra note 2, at .12, 20.

12 John H. Mueller, Michael Carlomusto, \& Alvin G. Goldstein, Orienting Task and Study Time in Facial Recognition, 11 Bull. Psychonomic Soc'y 313 (1978); K. E. Patterson \& A. D. Baddeley, When Face Recognition Fails, 3 J. Experimental Psych. (Hum. Learning \& Memory) 406 (1977); Gordon H. Bower \& Martin B. Karlin, Depth of Processing Pictures of Faces and Recognition Memory, 103 J. Experimental Psych. 751 (1974).

13 Brian R. Clifford \& Jane Scott, Individual and Situational Factors in Eyewitness Testimony, 63 J. Applied Psych. 352 (1978); Johnson \& Scott, Eyewitness Testimony and Suspect Identification as a Function of Arousal, Sex of Witness and Scheduling of Interrogation (paper presented at the meeting of the American Psychological Ass'n, Washington, D.C. 1976); see generally Loftus, supra note 2, at 33-35.

14 John W. Shepherd, Social Factors in Face Recognition, in Perceiving and Remembering Faces (Graham M. Davies, Hadyn D. Ellis, \& John W. Shepherd eds. 1981); John C. Brigham \& Paul Barkowitz, Do “They All Look Alike?' The Effect of Race, Sex, Experience and Attitudes on the Ability to Recognize Faces, 8 J. Applied Soc. Psych. 306 (1978); Roy S. Malpass \& Jerome Kravitz, Recognition for Faces of Own and Other Race, $13 \mathrm{~J}$. Personality \& Soc. Psych. 330 (1969).

15 Loftus, supra note 2, at 52-54; John W. Shepherd, Hadyn D. Ellis, \& Graham M. Davies, Identification Evidence: A Psychological Evaluation 80-86 (1982); see generally Hadyn D. Ellis, Practical Aspects of Face Memory, in Wells \& Loftus, supra note 2, at 2325 .

${ }^{16}$ Elizabeth F. Loftus \& Edith Greene, Warning: Even Memory for Faces May Be Contagious, 4 Law \& Hum. Behav. 323 (1980); see generally Hadyn D. Ellis, supra note 15, at 25-28; and Loftus, supra note 2 , at $52-87$. 
retrieved during the identification procedure so that the witness can attempt to judge whether a known person who is presented to hertypically in a physical or a photographic lineup-is the same person that she originally saw. Experimental studies ${ }^{17}$ concur with legal experience ${ }^{18}$ on the dangers at this stage: suggestive identification procedures can dramatically alter the choices that witnesses make, and even quite subtle factors can have powerful suggestive effects, inducing witnesses to make identifications when otherwise they would have made none or to choose a particular person whom they would not otherwise have chosen.

The experimental studies do not tell us how good witnesses are at the task of identifying strangers. Given the enormous variation in the circumstances of actual identifications and the great range of individual abilities, any general estimate of this sort would be meaningless. The studies do demonstrate, however, that many witnesses make mistakes in contexts that are, as far as we can tell, reasonable replications of common scenarios and that they are often very confident in their mistakes. Indeed the research in this area shows that it is dangerous to use the confidence of eyewitnesses as a basis for judging their accuracy. ${ }^{19}$ Unfortunately, most lay people seem to believe that confidence is a useful predictor of eyewitness accuracy ${ }^{20}$ (and, sadly, the Supreme Court has endorsed this doubtful proposition). ${ }^{21}$

Several studies suggest some specific ways that erroneous identifications might occur in the legal system. If the police have no particular suspect in mind they might ask the witness to look through a "mug book" containing hundreds of photographs of potential suspects and to try to

\footnotetext{
17 Roy S. Malpass \& Patricia G. Devine, Eyewitness Identification: Lineup Instructions and the Absence of the Offender, 66 J. Applied Psych. 482 (1981); R. C. L. Lindsay \& Gary L. Wells, What Price Justice? Exploring the Relationship of Lineup Fairness to Identification Accuracy, 4 Law \& Hum. Behav. 303 (1980); Anthony N. Doob \& Hershi M. Kirschenbaum, Bias in Police Lineups-Partial Remembering, 1 J. Police Sci. \& Ad. 287 (1973); Gary L. Wells \& Donna M. Murray, What Can Psychology Say about the Neil v. Biggers Criteria for Judging Eyewitness Identification Accuracy? 68 J. Applied Psych. 347, 357-58 (1983); M. S. Fanselow \& Robert Buckhout, Nonverbal Cueing as a Source of Biasing Information in Eyewitness Identification Testing (unpublished manuscript), cited in id. at 360 n. 4 .

18 For example, United States v. Wade, 388 U.S. 218, 228-30 (1967); see generally Sobel, supra note $5, \S 1.3$.

19 For a thorough review of the literature on the relation between confidence and accuracy in eyewitness testimony, see Gary L. Wells \& Donna M. Murray, Eyewitness Confidence, in Wells \& Loftus, supra note 2, at 155-70.

${ }^{20}$ Gary L. Wells, How Adequate Is Human Intuition for Judging Eyewitness Testimony? in Wells \& Loftus, supra note 2, at 258, 271-72.

21 Neil v. Biggers, 409 U.S. 188, 199 (1972).
} 
identify the person that she saw. ${ }^{22}$ This process has been replicated in the laboratory with the photograph of the target person (who is, of course, known to the researchers) inserted at various places in the mug book, and these studies show that the greater the number of pictures the witness must review before she reaches the picture of the person she has seen, the more likely she is to choose a different picture. ${ }^{23}$ Thus, if the picture of the actual criminal can never be reached because it is not in the mug book, the risk of misidentification is maximized. An analogous problem occurs with lineups. In a recent study, the witnesses to a staged theft were divided into two groups. One group was shown a photographic lineup that included the actual thief, and he was the most frequent choice among those who made positive identifications. The other group, however, was shown a lineup without the thief, and the pattern of their choices was indistinguishable from that of the first group: the same proportion of witnesses made confident identifications, and the same proportion focused on a single choice-this time a man who had no connection with the theft. ${ }^{24}$

Unfortunately, once the witness has chosen a photograph by mistake, she is not likely to change her mind, even when she is presented with an opportunity to identify the actual culprit. ${ }^{25}$ Nor are other people likely to correct this error for her. A series of studies have tested the performance of subjects who are placed in the role of jurors who must evaluate eyewitness testimony; these studies provide some evidence that jurors overvalue eyewitness evidence in general ${ }^{26}$ and strong evidence that they cannot tell accurate testimony from inaccurate. ${ }^{27}$

22 See, for example, Police Foundation, Model Rules, Eyewitness Identification 36 (Project on Law Enforcement Policy and Rulemaking 1974); and Sobel, supra note 5, § 10.3, at $10-12$.

23 David R. Lenorovitz \& Kenneth R. Laughrey, A Witness-Computer Interactive System for Searching Mug Files, in Wells \& Loftus, supra note 2, at 38-63; Laughrey et al., supra note 9.

24 David Dunning, Phoebe Ellsworth, \& Lee Ross, Accuracy, Confidence and Calibration in Eyewitness Responses to Valid and Blank Lineups (unpublished manuscript, Stanford Univ., Dep't Psychology, 1985).

${ }^{25}$ Gabriel W. Gorenstein \& Phoebe C. Ellsworth, Effect of Choosing an Incorrect Photograph on a Later Identification by an Eyewitness, 65 J. Applied Psych. 16 (1980).

26 Elizabeth F. Loftus, Reconstructing Memory: The Incredible Eyewitness, Psychology Today, August 1974, at 116-19; Loftus, supra note 2, at 8-13; R. C. L. Lindsay, Gary L. Wells, \& Carolyn M. Rumpel, Can People Detect Eyewitness Identification Accuracy Within and Across Situations? 66 J. Applied Psych. 79 (1981); but see McKenna, Mellott, \& Webb, Juror Evaluation of Eyewitness Testimony (paper presented at the meeting of the Eastern Psychological Ass'n, New York 1981); and Howard E. Egeth \& Michael McCloskey, Expert Testimony about Eyewitness Behavior: Is It Safe and Effective? in Wells \& Loftus, supra note 2, at 285-91.

${ }^{27}$ Lindsay et al., supra note 26; Gary L. Wells, R. C. L. Lindsay, \& Tamara J. Ferguson, 
In sum, the psychological research demonstrates that there are numerous common ways eyewitnesses can go wrong and little reason to believe that there is anything about their errors that will enable others to recognize them and to set them right.

\section{Attempted Solutions}

Several different legal procedures have been suggested to alleviate the dangers of eyewitness identification. I will describe these proposed solutions, or partial solutions, only briefly.

\section{A. Constitutional Rules}

The Supreme Court has addressed the use of eyewitness identifications under two constitutional provisions: the Sixth Amendment right to counsel and the due process clause of the Fourteenth Amendment.

Counsel at Identification Procedures. In 1967 the Supreme Court broke new ground in United States $v$. Wade $e^{28}$ and Gilbert v. California ${ }^{29}$ by requiring the presence of counsel for the accused at any confrontation at which a witness is asked to attempt to identify the defendant. ${ }^{30}$ If counsel was not present, evidence of the identification procedure was inadmissible, but the witness might still be permitted to identify the defendant in court if it was shown that she could do so on the basis of "observations other than the lineup identification." 31 But the right to counsel has not been retained as a safeguard against the risk of misidentification. In 1972 the Court held in Kirby $v$. Illinois ${ }^{32}$ that no such right exists for police-initiated identification procedures that take place prior to the filing of formal charges. Even before 1972 most identifications were probably obtained prior to the filing of formal charges; after Kirby that pattern has become more pronounced. In 1973 the Court completed this process in United States $v$. Ash ${ }^{33}$ by holding that the presence of defense counsel is never required at a photographic identification (the most common procedure) regardless of its timing.

Accuracy, Confidence and Juror Perceptions in Eyewitness Identification, 64 J. Applied Psych. 440 (1979).

28388 U.S. 218 (1967).

29388 U.S. 263 (1967).

30 The procedure at issue in Wade was a lineup; in Moore v. Illinois, 434 U.S. 220 (1977), the court made explicit what was implicit in Wade: that this right to counsel applied to any physical confrontation between the accused and a witness.

31 United States v. Wade, 388 U.S. 218, 240 (1967).

32406 U.S. 682 (1972). See also Moore v. Illinois, 434 U.S. 220 (1977).

33413 U.S. 300 (1973). 
The Due Process Test. In Stovall v. Denno, decided the same day as Wade and Gilbert, the Supreme Court held (independently of any right to counsel) that an identification might be the result of a confrontation that "was so unnecessarily suggestive and conducive to irreparable mistaken identification that [its use in evidence] denied [the defendant] due process of law." 34 A year later, in Simmons $v$. United States, ${ }^{35}$ the Court extended this holding to photographic identifications. This rule has proven more durable than has the right to counsel announced in Wade, but it too has taken a beating over the past eighteen years. Initially, Stovall was applied like Wade to exclude evidence of suggestive out-of-court identifications but to permit independently based in-court identifications by the same eyewitnesses. ${ }^{36}$ That was changed by Neil v. Biggers ${ }^{37}$ in 1972 and by Manson v. Brathwaite ${ }^{38}$ in 1977 , in which the Supreme Court held that the ultimate due process test for all identifications, in court and out, is not suggestiveness but "whether under the 'totality of circumstances' the identification was reliable even though the confrontation procedure was suggestive." ${ }^{39}$ Biggers and Brathwaite shifted the focus of the due process inquiry from the propriety of the conduct of the police in obtaining an identification to the likelihood that the identification is accurate-a difficult and touchy question; they "imported the question of guilt into the initial determination of whether there was a constitutional violation.",40 The effect has been predictable. Although many post-Brathwaite cases report patently suggestive pretrial identification procedures, only very few defendants have succeeded in keeping the resulting identifications out of evidence. ${ }^{41}$

34388 U.S. 293, 302 (1967).

35390 U.S. 377 (1968).

${ }^{36}$ See, for example, United States v. Cook, 464 F.2d 251 (8th Cir. 1972), cert. denied, 409 U.S. 1011 (1972); United States ex rel. Springle v. Follette, 435 F.2d 1380 (2d Cir. 1970); Frazier v. United States, 419 F.2d 1161 (D.C. Cir. 1969); People v. Caruso, 68 C.2d 183, 436 P.2d 336, 65 Cal. Rptr. 336 (1968); People v. Ballott, 20 N.Y.2d 600, 233 N.E.2d 103, 286 N.Y.S.2d 1 (1967).

37409 U.S. 188 (1972).

38432 U.S. 98 (1977).

${ }^{39}$ Neil v. Biggers, 409 U.S. 188, 199 (1972).

${ }^{40}$ Manson v. Brathwaite, 432 U.S. 98, 128 (1977) (Marshall, J., dissenting).

${ }^{41}$ There are numerous cases upholding the admission of identifications based on highly suggestive procedures. I will confine myself to listing some of the more startling examples: Komurke v. State, 562 S.W.2d 230 (Tex. Crim. 1978) (en banc) (witness shown two photographs of suspect and told "This is the man," but identification admissible because reliable); State v. Leigh, 580 S.W.2d 536, 543 (Mo. Ct. App. 1979) (ten-year-old victim of sexual assault shown single picture of suspect and told by police that he was a "bad man" who "does little things like that to little girls," but in-court identification deemed reliable); United States v. Bangert, 645 F.2d 1297, 1303 (8th Cir. 1981), cert. denied, 454 U.S. 860 
As a result of these revisions, the constitutional restrictions on the use of eyewitness identification evidence have little present force; and even in their previous and more powerful incarnations, they were designed to deal with only one of several causes of erroneous identificationssuggestive procedures initiated by the authorities.

\section{B. Nonconstitutional Proposals}

The two major nonconstitutional proposals to alleviate the problems of eyewitness identification have been the use of special cautionary jury instructions and of expert testimony on the dangers of this type of evidence. These proposals have had mixed success. Special jury instructions on eyewitness identification are given in a substantial fraction of trials in which they are appropriate, and they are not given in a comparable proportion of such cases. ${ }^{42}$ Expert testimony on eyewitness identification is sometimes offered at trial; in the past it was usually excluded, but that is changing. ${ }^{43}$ It is not clear how much these remedies actually improve the accuracy of jury decision making-the evidence on their effects is limited and mixed ${ }^{44}$-and in any event, many trials that turn on eyewitness

(1981) (witness shown photographs of three women, two black men, and six white men, only one of whom had a beard, when they knew they were looking for a white man with a full beard-but identifications were reliable); United States v. Hadley, 671 F.2d 1112 (8th Cir. 1982) (bank robbery suspect shown simultaneously-in handcuffs and surrounded by police officers-to four witnesses who had been told that the robber had been caught, but identifications were reliable). For a detailed and annotated discussion of the trends in lowercourt decisions applying due process standards to pretrial identifications after Biggers and Brathwaite, see Sobel, supra note 5, $\$ \$ 3.4,3.5,4.2(\mathrm{~d}), 5.3$.

42 The leading case on this issue is United States v. Telfaire, 469 F.2d 552 (D.C. Cir. 1972), in which the District of Columbia Circuit outlined a suggested cautionary instruction directing jurors' attention to several factors that they should consider in evaluating eyewitness identifications. American jurisdictions have split reasonably evenly between those requiring or recommending Telfaire-type instructions and those declining to do so. See Sobel, supra note 5, \& 9.7; Taylor, supra note 5, at 219-27; Edward J. Devitt \& Charles B. Blackmar, Federal Jury Practice and Instructions 474-81 (1977) (hereinafter cited as Devitt \& Blackmar, Federal Jury Practice); and Edward J. Devitt \& Charles B. Blackmar, 1985 Cumulative Supplement 322-25 (1985).

${ }^{43}$ Compare, for example, United States v. Amaral, 488 F.2d 1148 (9th Cir. 1973); United States v. Brown, 540 F.2d 1048, 1053-54 (10th Cir., 1976), cert. denied, 429 U.S. 1100 (1977); and People v. Brown, 443 N.E.2d 665, 668 (IIl. App. 1982) (upholding the exclusion of eyewitness identification experts) with State v. Chapple, 660 P.2d 1208 (Ariz. 1983); United States v. Smith, 736 F.2d 1103 (6th Cir. 1984); People v. McDonald, 37 Cal. 3d 351, 690 P.2d 708 (1984); and United States v. Downing, 753 F.2d 1224 (3d Cir. 1985) (requiring the admission of such expert testimony).

${ }^{44}$ In general, simulation studies have found that juries do not understand most of the instructions they receive. Bruce D. Sales, Amiram Elwork, \& James J. Alfini, Improving Comprehension for Jury Instructions, in 1 Perspectives in Law and Psychology: The Criminal Justice System (Bruce D. Sales ed. 1977); Robert P. Charrow \& Veda R. Charrow, 
identification evidence (perhaps most) are conducted without the benefit of either of these procedures.

In short, none of these proposed solutions is a plausible antidote to the problem of eyewitness identification. If judicial errors are as rare as they seem to be, we must look elsewhere for an explanation.

\section{The Structure of Criminal Adjudication}

The core of my argument is that eyewitness testimony is frequently less important to the determination of the identity of a criminal than it appears to be because the eyewitness evidence is corroborated by other information. This corroborating information may answer one or both of two questions, depending primarily on when it is obtained: (1) Why did the police come to suspect the defendant in the first place? (2) Why did the prosecutor persist in pressing the charges rather than accept the defendant's claim of innocence?

\section{A. Initial Investigation: Locating a Suspect}

The first and the most critical task in a criminal investigation is to locate the suspect. Often this is trivial-the criminal may be caught red-handed or turn himself in-but all cases in which identity is in dispute include this initial "whodunit" stage. It may last minutes or months; either way, the means by which it is resolved bears critically on the accuracy of any determination of identity farther down the line.

The quickest way to locate a suspect is by proximity: he may be found in the vicinity of the crime soon after it occurs. If that fails, the police often find a suspect through incriminating possessions-stolen property, an identified automobile, and so on. In some cases a suspect is initially

\footnotetext{
Making Legal Language Understandable: A Psycholinguistic Study of Jury Instructions, 79 Colum. L. Rev. 1306 (1979). The common cautionary eyewitness instructions are unlikely to be an exception to this pattern-they are wordy and complex-see, for example, Devitt \& Blackmar, Federal Jury Practice, supra note 42, § 15.19, at 477-78 - and they are usually buried in a mass of instructions on other issues. Still, such instructions might add force to arguments by defense attorneys.

Taken as a group, the few studies on the effects of testimony by experts on eyewitness identification are inconclusive. Harmon M. Hosch, E. Link Beck, \& Patricia McIntyre, Influence of Expert Testimony regarding Eyewitness Accuracy on Jury Decisions, 4 Law \& Hum. Behav. 287 (1980); Elizabeth F. Loftus, Impact of Expert Psychological Testimony on the Unreliability of Eyewitness Identification, 65 J. Applied Psych. 9 (1980); Gary L. Wells, R. C. L. Lindsay, \& J. P. Tousignant, Effects of Expert Psychological Advice on Human Performance in Judging the Validity of Eyewitness Testimony, 4 Law \& Hum. Behav. 275 (1980); Elizabeth F. Loftus, Expert Testimony on the Eyewitness, in Wells \& Loftus, supra note 2, at 273-82. In general, the available evidence suggests that expert testimony makes jurors more mistrustful of eyewitness identifications but does not improve their ability to distinguish accurate and inaccurate eyewitness testimony.
} 
identified by a police informant, typically an anonymous or confidential one; in other cases they may focus on a suspect because of what they know about his character-convictions for comparable crimes or other patterns of culpable behavior. Finally, a suspect may be located by his appearance: an eyewitness may pick his picture out of a mug book or some other array of many photographs, or the victim may run into him in a public place, or a nonwitness may notice his resemblance to a description or a composite picture of the criminal.

These different methods of locating a suspect provide different levels of corroboration for any subsequent eyewitness identification. Proximity to the scene and time of the crime is substantial independent corroboration of eyewitness evidence, provided the eyewitness identification is in fact independent of that proximity, that is, that it was not suggested by the police on the basis of their initial suspicion. Similarly, incriminating possessions, informant tips, and character evidence, while all inconclusive in themselves, add independent bases for confidence in the accuracy of an eyewitness identification (assuming again that the identification was not suggested by the police). On the other hand, the fact that a suspect's appearance resembles that of the criminal adds no information to an eyewitness identification of him as the criminal since it is merely a weaker version of the same information.

\section{B. Pretrial Proceedings: Clearing the Innocent}

The police may find additional items of incriminating evidence after the suspect is located, and some of them may be extremely probative-latent fingerprint matches, for example, or a confession from the defendant. Often this evidence will remove any doubt about the accuracy of the eyewitness identifications. On the other hand, contrary evidence may emerge. The eyewitnesses may contradict each other or become less certain, or exonerating evidence may turn up. In particular, the defendant may be cleared by physical evidence-the wrong fingerprints or blood type, for example-or by a clear alibi, or by the identification of the actual criminal. Ordinarily, if any of these things happen, the charges against the misidentified suspect will be dismissed. If there is some doubt, the prosecutor may be swayed by lie detector (polygraph) evidence that the defendant is innocent.

The net result of this process is to reduce the chance of misidentification at trial by sparing some misidentified defendants from exposure to that risk. To be sure, the charges against many guilty defendants are also dismissed because of insufficient admissible evidence to convict (the absolute number of such cases may be much greater than the number of 
dismissals based on actual innocence), ${ }^{45}$ but a defendant who was misidentified stands a better chance, perhaps a much better chance, of obtaining a pretrial dismissal. The authorities are less likely to find evidence corroborating his guilt and much more likely to find-or to be presented with-convincing affirmative evidence of his innocence.

The majority of serious criminal cases, however, end not in dismissal but in negotiated pleas of guilt. ${ }^{46}$ In determining what plea bargain to offer, prosecutors take the strength of the evidence of guilt into account, and in a case in which a conviction at trial seems relatively unlikely a prosecutor may offer an unusually lenient disposition-probation and time served awaiting trial, for example. Some defendants who have been misidentified undoubtedly receive offers of this sort, either because the identification evidence looks shaky or for some other reason, and some probably accept them, especially if they have criminal records and face potentially draconian sentencing if convicted at trial. Nonetheless, other things being equal, an innocent defendant will be less likely to plead guilty than a guilty one-in most circumstances, I would think, far less likelyand his friends, his family, and his lawyer are more likely to discourage him from doing so (if they have confidence in his innocence). As a result, while plea bargaining may cause a few misidentified defendants to plead guilty, its major effects are to reduce the number of cases in which identity is contested and to channel to trial most misidentification cases that are not dismissed.

\section{Trial: Inadmissible Evidence}

If charges are not dismissed and if the defendant does not plead guilty, a criminal case will generally go to a jury trial, where the likely outcome is conviction. At that point much of the information that may corroborate eyewitness identification testimony becomes invisible. The jury will usually hear if the defendant was found near the scene of the crime (although some studies suggest that they may not always appreciate the importance of facts of that sort), ${ }^{47}$ and they will know if the defendant fails to present

\footnotetext{
45 See, for example, U.S. Dep't Justice, supra note 7, at 463 (18.1 percent of federal felony prosecutions in 1980 ended in dismissal).

46 Id.

47 A famous set of psychological studies shows that people tend to underrate the value of information about the base rates at which events occur and, correspondingly, overrate information that touches on the individual event before them. Amos Tversky \& Daniel Kahneman, Causal Schemes in Judgments under Uncertainty, in Judgment under Uncertainty: Heuristics and Biases 49, 61-71 (Daniel Kahneman, Paul Slovic, \& Amos Tversky eds. 1982). The situation here is similar but not identical to that studied by Tversky and
} 
a credible alibi (although in theory they may not consider that as evidence of guilt). But other common types of corroborating information will not be apparent. Evidence about the defendant's background and character is almost always inadmissible, informant tips are rank hearsay, physical evidence is sometimes inadmissible as the fruit of an illegal search and sometimes becomes inadmissible because it is mishandled by the police, etcetera. As a result, juries are forced to rely on eyewitness evidence to a greater extent than are other actors in the criminal justice system, and they are at a disadvantage in the task of sorting the innocent defendants from the guilty.

If the psychological literature in this area tells us anything, it is that juries cannot reliably judge eyewitness identification evidence. In addition, it is notorious that there is a large element of chance in any jury trial. Still, jurors may have some limited skill at evaluating eyewitness testimony. There is evidence, for example, that while they are all but unable to distinguish between accurate and inaccurate eyewitnesses, they are able, to an extent, to recognize conditions of observation that are conducive to accuracy. ${ }^{48}$ More important, eyewitness evidence is rarely considered in a vacuum. If the defendant is in fact guilty the prosecution is more likely to have other admissible evidence to prove it, and the defendant is less likely to present credible evidence of innocence. A misidentified defendant who goes to trial undoubtedly runs a terrible risk of being convicted in error, but it does not take blind faith in trials by jury to believe that that risk is considerably smaller than it is for a guilty defendant and that even this highly imperfect filter reduces the number of erroneous convictions considerably.

\section{Patterns of Misidentification}

My description of the process of criminal adjudication is a hypothesis; its truth is an empirical issue. One way to study that issue-an imperfect one-is to examine patterns in cases in which the system has failed, that is, reported instances of misidentification.

\section{A. The Nature of the Inquiry}

Most empirical research on eyewitness identification has followed the traditional experimental paradigm: subjects who witness an event are

\footnotetext{
Kahneman: the fact that a suspect was found near the scene of a crime is background information that bears on the chance that he committed it (in contrast to testimony, however shaky, that purports to actually identify him), but it is a different sort of background information than that used in their research.

48 Lindsay et al., supra note 26.
} 
divided at random into two groups, an "experimental" group that receives a "treatment" (for example, misleading questioning) and a "control" group that does not. Both groups are then tested on their recollection of the event; if the experimental group makes significantly more errors than the control group, then the only possible cause for that difference is the treatment. Such studies have limitations. In particular, they are open to the criticism that effects that are observed in a laboratory may not occur on the street. But on the whole the experimental method is an appropriate way to investigate the psychological causes of misidentification, and eyewitness identification is a congenial and natural setting for experimental psychology - two facts that may explain a good deal of the popularity of this type of research.

Unfortunately, the questions that are the subject of this article are not susceptible to experimental investigation. In part the problem is technical; my inquiry focuses on the informal mechanisms that are used to sort criminal cases before trial, and these mechanisms would be difficult or impossible to reproduce in a laboratory. But there is also a more basic, conceptual difficulty. My major claims do not concern the psychological causes of eyewitness errors but rather the relative value of different types of information that bear on the identification of suspects as this information occurs in actual criminal cases. Propositions of this type cannot be tested experimentally. No experiment in a laboratory can prove or disprove the hypothesis that black voters in the United States are more likely than whites to vote Democratic; the issue is the relative frequencies of different combinations of facts in the real world, and those must be observed directly. The same applies to the hypothesis that criminal suspects who were spotted in chance encounters with eyewitnesses are more likely to be misidentified than are those who were first mentioned by informants.

In theory, one could study the process of criminal identification by gathering data on a large number of investigations and then comparing those that produce misidentifications with those that do not. In practice there are insurmountable barriers to this strategy. Existing records are of very limited value; police agencies maintain only spotty information on most criminal investigations, especially since so many of them are routine. Conceivably, one might collect such information by following a sample of criminal cases from their inception, but that method would be difficult, expensive, time consuming, and exceedingly inefficient since only a small minority of those cases would result in misidentifications. Moreover, even if this were done, the comparisons that could be made would be of uncertain value since in many cases there would be no way to know whether a misidentification had occurred.

In this paper I have attempted to investigate the patterns of eyewitness 
misidentification by a third method-an examination of stories of reported instances of misidentification. This method has an important advantage: such stories focus efficiently on the item of interest-misidentification. Unfortunately, it also has two major limitations. First, there is no way to determine the proportion of reported misidentifications that are included in my sample or to determine how representative they are of the universe of such cases, let alone to estimate the size or the characteristics of the universe of all misidentifications. Second, this is a one-sided data set. I have no information on cases in which the defendant was accurately identified with which to compare the misidentifications. These limitations impose severe restrictions on the conclusions that can be drawn from these data. Some of the patterns that I have found are strong enough to inspire confidence, but for the most part the factual conclusions that can be drawn from this research are tentative.

\section{B. Sources of Data}

Few misidentification cases ever appear in any of the myriad of case reports, journals, loose-leaf services, and other periodical publications that are so central to the practice of law. The reason for their absence is simple: once a misidentification is established it is generally remedied in some summary fashion that leaves little or no official written imprint. Pending charges will be dismissed. Convicted defendants may be granted new trials at which charges will be dismissed, or they may be pardoned or receive some other form of executive clemency. Formal hearings do occur in some cases, although they are not the rule, but they rarely produce written opinions and are almost never subject to appellate review. As a result the best sources for reports on misidentification cases are the news media-newspapers, magazines, and wire services-and books that compile stories that appeared originally in the news media. My search of these sources, by no means an exhaustive one, has yielded a total of 136 proven cases of misidentification.

The misidentification cases that I have gathered can be divided into two groups of comparable size: seventy-five "old" cases that involve crimes that occurred before the Wade decision was announced in June 1967 and sixty "recent" cases that came after Wade (and one case from the late 1960 s that cannot be dated by reference to Wade). ${ }^{49}$ The old cases are

\footnotetext{
49 Twelve of the cases reported here involve two suspects who were misidentified as the criminals in a single crime, and three cases involve three suspects. I have (somewhat arbitrarily) counted all these multiple-suspect incidents as single cases with the exception of two cases in which the treatment of the two suspects followed divergent paths: (1) the case of a husband and wife who were charged with the same crime and tried on the same evidence
} 
taken primarily from books that contain collections of stories on wrongful convictions, although most of the information for these stories came originally from newspapers. The great majority of these stories were found in three books: a book by Edwin Borchard published in $1932,{ }^{50}$ a book by Jerome and Barbara Frank from 1957, ${ }^{51}$ and one by Edward Radin from $1964 .^{52}$ With several exceptions, all the recent cases that I found were reported directly in the news media. The majority of these recent cases are described in newspaper and magazine articles that I gathered or that were sent to me by several helpful friends. ${ }^{53}$ In addition I conducted a computer search in early July 1984 for all Associated Press wire stories (starting January 1977) and all United Press International wire stories (starting September 26, 1980) that included the word "mistaken," the words "identity," "identify," or "identification," and the word "witness." 54 This search produced new information on about half of the recent cases that $I$ had already found and an approximately equal number of fresh cases.

The set of misidentification cases that I have gathered here is large as such collections go, apparently the largest that has been assembled. ${ }^{55}$ The list is not complete in any sense. Additional cases could be found in news stories, wire stories, and books that $I$ have not examined. The stories that I did find vary enormously in the amount of information that they include; some, perhaps two dozen, were so scanty that I excluded them from the set of cases I examined. Otherwise, while I have not attempted to find every case I could possibly locate, I have included each case that I discovered in the sources that I used. My goal has been to collect enough

but before different juries, one of which convicted the husband while the other acquitted the wife; and (2) the case of two suspects in the same robbery who were identified months apart by unrelated means, tried separately, and convicted separately. A total of 157 suspects are included in these 136 cases-151 men and six women. (Accordingly, I have generally used male pronouns to refer to suspects and defendants.) Nearly half of the suspects were in their twenties when they were charged, and about 85 percent were not yet forty.

so Edwin M. Borchard, Convicting the Innocent (1932).

51 Jerome Frank \& Barbara Frank, Not Guilty (1957).

52 Edward D. Radin, The Innocents (1964). In addition, smaller numbers of cases were found in Hugo Bedau, The Death Penalty in America: An Anthology 434-52 (rev. ed. 1967); Robert Ferguson \& Allan Miller, The Polygraph in Court (1973); Loftus, supra note 2; and Wells \& Loftus, supra note 2.

${ }^{53}$ I am particularly grateful to Linda Lenker and Elizabeth Loftus, each of whom allowed me to copy her files of misidentification stories.

54 The search was conducted on the NEXIS (Mead Data) data base.

s5 Arye Rattner, Convicting the Innocent: When Justice Goes Wrong 17 (unpublished Ph.D. dissertation, Ohio State Univ., 1983), includes a tabulation of the causes of 205 cases of wrongful convictions, of which 100 (49 percent) were caused by misidentifications. This is, as far as I know, the largest reported list of such cases to date. 
misidentification cases to capture the range of common scenarios and to begin to explore some common patterns. ${ }^{56}$

\section{The Cases 57}

My data set is restricted to undisputed misidentifications, by strangers, of people accused of crimes that were committed in or after 1900. I have classified a case as undisputed if either of two conditions is met: (1) there has been a judicial or executive determination of the innocence of the accused or (2) the prosecuting authority that originally charged the defendant now agrees that he or she is in fact innocent. I have not included cases simply on the ground that a convicted defendant claims, even plausibly, that he is innocent. Nor have I included cases in which, without more, the defendant was acquitted by a judge or jury or in which his conviction was reversed by an appellate court for insufficient evidence of identity or for improper use of suggestive identification procedures. Acquittals and reversals are not usually based on affirmative findings of innocence but rather on deficient evidence of guilt, and they do not necessarily dissipate the suspicion against an accused person. One of the misidentified defendants in this set, for example, became the suspect in an extortion case primarily because he had been previously tried for a similar extortion scheme and acquitted. ${ }^{58}$

The misidentification cases reported here are unevenly distributed across the twentieth century, as Table 1 reveals. The majority of the cases involve crimes that were committed in two distinct periods1920 through 1939 and 1970 through 1983 -while relatively few cases originated before 1920 or between 1940 and 1969. This skewing reflects my sources. Brochard's cases are all from before 1932, and Frank and Frank and Radin also focus on the 1920s and 1930s. I have found no

\footnotetext{
56 In reporting my findings I make no reference to tests of statistical significance or other inferential statistics. As applied to the somewhat haphazard sample at my disposal, such statistics would be inappropriate and potentially misleading. For a highly readable description of this problem, see David Freeman, Robert Pisani, \& Roger Purves, Statistics 320-86 (1978).

57 References to the misidentification cases in these data include citations to the source(s) of the story or stories, followed by the name of the suspect(s) in parentheses, for example, N.Y. Times, January 1, 1985, at 1 (John Smith). If a story was taken from a wire service, the citation will identify the source and the date, for example, Associated Press, December 25, 1985.

58 Associated Press, June 14, 1980 (Richard Williams). Eight of the cases that I located were excluded from the sample because the misidentification was not undisputed. An additional three cases were excluded because the victims of the misidentifications were not strangers but acquaintances whom the witnesses mistakenly thought they had seen and recognized.
} 
TABLE 1

Misidentification Cases by Decade

\begin{tabular}{lc}
\hline Decade & Number of Cases \\
\hline $1900-1909$ & 1 \\
$1910-19$ & 3 \\
$1920-29$ & 23 \\
$1930-39$ & 25 \\
$1940-49$ & 6 \\
$1950-59$ & 12 \\
$1960-69$ & 8 \\
$1970-79$ & 36 \\
$1980-83$ & 17 \\
\hline \multicolumn{2}{c}{ NorE.-Five cases from the late 1960s or early } \\
1970 s could not be classified as to decade.
\end{tabular}

comparable books that focus primarily on wrongful convictions in the $1940 \mathrm{~s}, 1950 \mathrm{~s}$, and 1960s, and the cases that I found directly in newspaper and magazine articles and in wire service stories are concentrated in the 1970s and 1980s.

The great majority of the misidentification cases (88 percent [120/136]), concerned crimes of violence, often multiple crimes. Robberies accounted for 60 percent of these violent crimes (73/120) either alone (fiftysix cases) or in conjunction with other crimes (seventeen cases). Nearly one-quarter of the violent crimes involved rape (27/120) either separately (eighteen cases) or with other charges (nine cases); twenty-four cases involved homicides, mostly felony homicides, and at least half in the context of robberies or attempted robberies; and nine cases involved kidnappings. A small minority of the misidentifications, 16/136, occurred in the context of nonviolent crimes. Eleven of these sixteen cases were "bad-paper" crimes-forgery, check fraud, passing counterfeit bills, etcetera-one was a larceny, one was a burglary, two were drug offenses, and one was an indecent exposure. All of these cases were felonies and mostly toward the serious end of the felony range.

The distribution of these crimes indicates that in serious felony cases misidentifications are most common for violent crimes, particularly robbery. Very little can be inferred about misidentifications of suspects for lesser crimes except that such errors are rarely reported in the press and perhaps rarely detected at all.

\section{Form of Adjudication}

Convictions and Dismissals. Ninety-seven of the misidentification cases in this sample produced convictions, and thirty-nine cases did not. 
With two partial exceptions, the cases that did not result in convictions all ended in the dismissal of the charges or in uncontested adjudications of innocence, such as directed verdicts, rather than in acquittals. The absence of acquittals from this sample obviously does not reflect an absence of acquittals among cases in which defendants are identified in error. Rather, it undoubtedly reflects the fact that a convicted defendant and his friends may go to great lengths to secure affirmative evidence and an affirmative adjudication of innocence, but they will have little interest in doing so if he is found not guilty. The two cases in which acquittals played some role illustrate this process. In one case ${ }^{59}$ the defendant was identified thirteen times and charged five times as the man who had committed a string of robberies and related crimes; four times the charges were dismissed and once he was acquitted, but that did not end his ordeal. Finally, after yet another robbery and kidnapping, the actual criminal was found, and he was cleared for good. In the other case ${ }^{60}$ a misidentified woman was acquitted of a robbery, but her husband was convicted of the same crime on identical evidence; ultimately, the actual criminal was caught and confessed. If both husband and wife had been acquitted in the first instance the matter would probably have ended there. ${ }^{61}$

All but four of the pre-Wade cases resulted in convictions, while thirtyfive of the sixty post-Wade cases did not produce convictions. This disparity, like the temporal skewing of the sample, reflects the sources of these cases. The old cases are almost all taken from books on convicting

59 San Francisco Sunday Examiner \& Chronicle, January 4, 1981, at 14A; Wells \& Loftus, supra note 2, at 1-2 (Robert Dillen).

60 Borchard, supra note 50, at 105 (Frank and Norma Howell).

61 The reason for the paucity of acquittals in this sample is illustrated by the case of Anthony Williams, who was charged with a robbery in Garland, Texas, in 1983. United Press International, November 8-9, 1983. Williams's roommate was Lenell Geter, who spent fourteen months in custody as a result of a conviction in a related misidentification case. For example, Associated Press, December 17, 1983, and March 25, 1984; N.Y. Times, March 22, 1984; and CBS News, 60 Minutes, December 4, 1983. Geter was released after his case became the focus of intense national publicity and was ultimately exonerated when the police arrested another man for the same crime. Williams, however, came to trial after this public attention had focused on the Geter case and was acquitted in the first instance. He is not included in this sample because the prosecution continued to assert his guilt despite the acquittal.

The sample includes a few cases in which the suspect was acquitted by a jury or a judge without opposition from the prosecution. Such acquittals amount, in effect, to dismissals; the cases in which they occurred have been classified as "convictions" if there was an earlier conviction, otherwise as "dismissals." For example, in one case that I classified as a conviction, the defendant was convicted twice and each conviction reversed. At his third trial the police presented fingerprint evidence that cleared him, and the case-no longer contested-was presented to the jury, which acquitted him. Borchard, supra note 50, at 23 (Payne Boyd). 
the innocent, and few cases that were dismissed without convictions are included in those collections. By contrast, the news articles on the newer cases exhibit no such obvious bias. As a result it is possible to make some tentative comparisons between those cases that ended in convictions and those that did not, but these comparisons are restricted to the post-Wade period.

Guilty Pleas. Only two of the ninety-seven convictions in this set resulted from a guilty plea. In one case the defendant was motivated in part by the fact that he also faced unrelated felony charges for which he was guilty, ${ }^{62}$ and in the other the defendant was convinced that he would be sentenced to death and executed if he did not plead guilty. ${ }^{63}$ On the other hand, several misidentification stories mention that the defendant refused a highly attractive plea bargain only to be convicted and receive a much harsher sentence ${ }^{64}$ or that the defendant had pled guilty to another charge but not to the erroneous one. ${ }^{65}$ Three defendants who did not plead guilty confessed to the crimes with which they were charged-two, apparently, under coercion ${ }^{66}$ and the third because he thought he might in fact have committed the crime while on drugs. ${ }^{67}$

This paucity of guilty pleas stands in sharp contrast to the well-known fact that at least 80 percent of all criminal convictions in this country are based on pleas of guilt. ${ }^{68}$ A possible explanation for this disparity is that an innocent defendant is less likely to be exonerated after a plea of guilty than after a jury verdict: he is less likely to be able to convince others of his innocence (and perhaps less likely to try), and, since his sentence will probably be lighter (perhaps much lighter), there will be less pressure to right the wrong. This is probably true, but $I$ doubt if it can explain the nearly total absence of guilty-plea cases from this sample of misidentifications, especially since many of these misidentifications were discovered and corrected without any particular effort by the defendant. ${ }^{69}$ It is also

${ }^{62}$ Borchard, supra note 50, at 367 (James Willis).

${ }^{63}$ Radin, supra note 52, at 151 (Louis DeMore).

${ }^{64}$ For example, Borchard, supra note 50, at 330-32 (Mary Berner); San Francisco Examiner, November 25, 1980, at A3 (Douglas Forbes); Frank \& Frank, supra note 51, at 191 (Alvernon Lyle); Borchard, supra note 50, at 195-200 (James W. Preston).

${ }^{65}$ For example, Borchard, supra note 50, at 347-49 (Elmer P. Jacobs).

${ }^{66}$ Southern Poverty Law Center 2, January-February 1982 (unpublished newsletter). (Johnny Ross); Frank \& Frank, supra note 51, at 165 (Maurice Taff).

67 Radin, supra note 52, at 149-51 (Daniel Kamacho).

68 For example, in the year ending on June 30,1980, 81 percent of criminal convictions in federal courts were based on guilty pleas-U.S. Dep't Justice, supra note 7, at 463-as were 91 percent of the Superior Court convictions in California in 1980; see California Dep't Justice, supra note 7 , at 45 .

${ }^{69}$ See notes 89-93 infra and accompanying text. 
possible that a misidentification that is discovered is less likely to be reported in the media if the defendant had pleaded guilty. Still the pattern here is strong enough to suggest that despite the common concern that plea bargaining has a coercive effect on innocent defendants, ${ }^{70}$ few defendants who are misidentified plead guilty to serious felony charges.

\section{E. The Process of Misidentification}

Original Suspicion. The basis of the original suspicion against the suspect can be determined from ninety-two of the 136 stories in this set, and in nearly 60 percent of these cases (54/92) the suspect was first located by his appearance. In some of these cases the suspect would not have been identified but for some fact that made him an object of attention, typically the fact that he had been arrested or convicted of a crime. Such background facts may tend to corroborate a suspicion based on the suspect's appearance, however slightly, and may, in some instances, influence a witness to make an identification, but they do not point to a unique suspect. The essential feature of the cases in this category is that the suspect, however disreputable generally, was not individually linked to the particular crime at issue until someone pointed a finger at him because of his appearance. There are many different ways that a suspect can be located by appearance, but those represented in these data fall in approximately equal numbers into three broad categories, as follows.

In about one-third of the cases in which the suspect was first located by appearance (19/54), this identification was the result of a deliberate police-initiated screening procedure. In most of these cases a witness chose the suspect's picture from a "mug book" or its functional equivalent-a collection of pictures of generally suspicious people, usually people with police records - that was presented to the witness in the hope that he or she would spot the criminal. In addition, two suspects were picked out of high school yearbooks, and in three old cases the suspects were placed in what amounted to live mug books: they had been arrested for crimes unrelated to the incidents for which they were ultimately identified and were displayed in person along with other arrestees to eyewitnesses to various unsolved crimes.

Just over one-third of the suspects who were located by their appearance $(20 / 54)$ were spotted because they resembled a description or a composite drawing of the criminal. In most of these cases $(14 / 20)$ the

70 See, for example, Albert W. Alschuler, The Changing Plea Bargaining Debate, 69 Calif. L. Rev. 652, 713-16 (1981); and Kenneth Kipuis, Criminal Justice and the Negotiated Plea, 86 Ethics 93 (1976). 
resemblance was first noticed by a police officer, generally because the suspect was or had recently been in custody on other charges (four cases) or because the police officer knew the suspect before the crime or happened to run into him after it (six cases). In five cases, however, the suspect's resemblance to the description of the criminal was first noticed by civilians-including a priest whose similarity to a composite drawing of a robber was pointed out by a former parishioner ${ }^{71}$ and the manager of an ambulance company who became a rape suspect when coworkers saw a widely circulated composite drawing of the rapist ${ }^{72}$ - and in one remarkable case the resemblance was pointed out by the misidentified suspect himself. ${ }^{73}$

In the remaining cases in which a suspect was first identified by appearance $(15 / 54)$, the identification was the result of a spontaneous encounter with an eyewitness. Most of these identifications appear to have been completely fortuitous. A good example is the case of Manny Balestrero, who walked into his insurance office to ask about a loan and was mistaken for the man who had robbed the office twice, a month earlier and six months earlier.$^{74}$ In four of these cases, however, the suspect was spotted by a witness in the course of an investigation of the crime. A few spontaneous identifications may have been suggested by the circumstances of the encounter; in one case, for example, a man who had been robbed by an assailant who identified himself as a police officer thought he recognized an auxiliary policeman as the criminal when he saw the policeman sitting in a patrol car. ${ }^{75}$

Among the minority of the cases in which the suspect was located by means other than his appearance, the grounds for suspicion varied widely. The only sizable block is a group of eight cases, about one-fifth of the total in this category $(8 / 38)$, in which a misidentified suspect came to police attention because of his association with one or more of the actual criminals. In thirteen other cases the original suspicion was based on some other form of circumstantial evidence, but the type varied: in two cases the actual criminal used the suspect's name, in one he told his victim that he had managed the suspect's drugstore, two sets of suspects were found with guns in their cars, one suspect inadvertently wrote a bad

\footnotetext{
71 San Francisco Sunday Examiner \& Chronicle, June 22, 1980, at 15A; N.Y. Times, August 24, 1979, at 12A (Rev. Bernard Pagano).

${ }^{72}$ San Francisco Sunday Examiner \& Chronicle, November 9, 1980, at 2E (Gregory Taylor).

${ }^{73}$ Radin, supra note 52, at 151-54 (Louis DeMore).

${ }^{74}$ Life, June 29, 1953, at 97-107 (Manny Balestrero).

75 Social Action and the Law Newsmagazine, Vol. 6, No. 5 (1980) (Thomas Clarkson).
} 
check and so on. An additional five suspects were seen in the general vicinity of the crimes, although only one of these was spotted immediately after the crime was committed. Five suspects came to police attention because of character evidence, in some cases very weak character evidence (for example, a man who took two girls to a party without the permission of their parents became a suspect in several brutal rapes) ${ }^{76}$ five suspects were first mentioned directly or indirectly by informants (including one suspect who was identified perjuriously by the actual criminal as his accomplice) $;{ }^{77}$ and one was found with a gun that had been used in the murder for which he was charged. ${ }^{78}$

In sum, the suspect's appearance was the dominant basis of initial suspicion in the misidentification cases in this data set, both before and after Wade. ${ }^{79}$ This category accounts for almost 60 percent of the total, a fraction that is undoubtedly much higher than the comparable proportion for all criminal prosecutions or for prosecutions for violent crimes. By contrast, other common methods of locating suspects are rare among these misidentification cases. In particular, there are only a handful of cases in which the suspect was located on the basis of character, proximity to the crime, or an informant's tip.

Number of Witnesses. The number of eyewitnesses could be deter-

76 Frank \& Frank, supra note 51, at 50-57 (Ernest Mattice).

77 Borchard, supra note 50, at 370-74 (Luigi Zambino).

78 United Press International, June 22, 1982; June 23, 1982; June 24, 1982; and August 29 , 1982 (George Reissfelder).

79 There is an apparent historical trend in the data-initial suspicions based on appearance accounted for 49 percent of the pre-Wade cases $(29 / 59)$ and for 76 percent of the postWade cases $(25 / 33)$ in which the basis for the suspicion could be determined. This trend, however, seems to be related to a systematic difference in the absence of data on this issue: the basis of the initial suspicion could be determined in 79 percent of the old cases $(59 / 75)$ but in only 55 percent of the new cases $(33 / 60)$. This pattern suggests that the prevalence of initial suspicions based on appearance might be overestimated in these data. Since appearance is a less common basis of suspicion among the cases for which the data are more complete, it is possible that it would become less prevalent overall if all the missing data were filled in. This possibility also fits the nature of the stories. An initial suspicion based on appearance might be likely to figure even in a sketchy report of a misidentification case, for example, a newspaper article, which is a type of report that is more common among the post-Wade cases. By contrast, the fact that the suspect was first named by an informant might be mentioned (if at all) only in a more detailed description, for example, in a book, and these descriptions are more common among the pre-Wade cases. Fortunately, we can put a bound on the magnitude of this potential overestimate. Initial suspicions based on appearance occurred in 40 percent of all cases in this data set whether or not the basis of the initial suspicion is reported (54/134), and that proportion is nearly the same before Wade (39 percent) and after ( 42 percent). This is necessarily an underestimate; the true proportion of reported misidentifications with initial suspicions based on appearance probably falls somewhere in the neighborhood of 50 percent to 60 percent, a high proportion whatever its precise size. 
mined in 110 of these cases, and some information on the number (more than one, more than three, and so on) could be recovered in another ten cases. In a high proportion of these cases ( 60 percent [72/119]) the suspect was misidentified by more than one eyewitness. ${ }^{80}$ This indicates that two eyewitnesses may not be better than one-and also, perhaps, that policemen, prosecutors, and jurors are insufficiently aware of that fact and may place undue confidence in the testimony of multiple eyewitnesses.

Quality of the Evidence. The stories that are collected here are highly variable in the amount of detail they include on the nature of the evidence of identification. On the whole they contain relatively little information on this issue, and those that report cases that ended in dismissals tend to be worse than those that describe convictions. As a result it is impossible to make any overall statements about the quality of the identification evidence; nonetheless, it is interesting to describe the range in the quality of evidence among those cases that produced convictions, especially since the low end of that range is very low indeed.

A few of these cases included substantial evidence corroborating the mistaken identifications, but only a few. ${ }^{81}$ In a larger number of cases the defendant was handicapped by some form of character evidence, typically a criminal record. ${ }^{82}$ In one case, for example, the judge candidly explained that "I am always hesitant to convict anyone on eyewitness identification, but in this case I was swayed by the fact that the defendant denied [his true identity], had a fictitious identification, and had been previously convicted of a felony." ${ }^{, 83}$ A larger portion of the convictions,

80 About 85 percent of the multiple witness cases (52/61) involved five witnesses or fewer, but a few were more extreme. Two suspects, for example, were misidentified by seventeen witnesses each-Borchard, supra note 50, at 1-7 (Herbert T. Andrews); Los Angeles Times, June 23, 1972 (Frank J. Doto)-and another suspect was erroneously identified as an escaped convict by twenty-four witnesses who had known the actual criminal to a greater or lesser extent. Borchard, supra note 50, at 23-28 (Payne Bryd). The mean number of witnesses for all cases was 2.9 and for the multiple-victim cases 3.7.

81 See note 78 supra (George Reissfelder) (murder weapon found on suspect); Radin, supra note 52, at 51-53 (Eugene D. Tucker) (actual criminal cashed checks using suspect's name and driver's license).

82 Generally, a defendant's criminal record is admissible, if at all, only to impeach his credibility as a witness and not as substantive evidence of guilt. See, for example, Fed. $\mathbf{R}$. Evid. 609. This distinction may have significant practical consequences in other contexts (I doubt it), but in an identification case it is all but meaningless since the credibility of a defendant's testimony that he did not commit the crime is essentially synonymous with his claim of innocence. In one misidentification case, for example, Borchard states that "[w]hen evidence of [the defendant's] prior convictions was introduced, his plight became critical." Borchard, supra note 50, at 163 . In several of these cases defendants decided not to testify in order to avoid impeachment with prior convictions, a fact that may well have contributed to their convictions. For example, San Francisco Chronicle, March 5, 1981 (Aaron Owens); and Borchard, supra note 50, at 281-85 (George Hughes).

${ }^{83}$ Los Angeles Times, April 3, 1965, § 2, at 12 (Claude T. McGill). 
however, perhaps a majority, were based exclusively on eyewitness testimony, and in some instances this testimony was exceptionally hard to credit. In one case, for example, a father claimed to be able to identify the defendant as the masked robber who had killed his son, on the basis of "his high cheek bones, hollow cheeks, light hair, height and general build" ',84 the defendant was convicted on that evidence alone. In another case the defendant was identified as a masked bandit by several witnesses on the basis of "a similarity in the eyes, the lower part of the forehead and the upper part of the nose, these features being all that was visible behind the mask. "85 He too was convicted with no corroborating evidence.

Many misidentified defendants were convicted despite alibi evidence proving that it was impossible for them to have committed the crimes with which they were charged. In some cases these alibis were provided exclusively by friends or relatives of the defendants. Alibis of that sort are generally distrusted by police, prosecutors, and juries, and perhaps properly so. In other cases, however, it is hard to understand how the defendants' evidence could have been disbelieved. Lenell Geter, for example, was convicted of a robbery solely on the basis of eyewitness identification evidence despite testimony from nine coworkers that he was at his job at the time, fifty miles away, and that they were not likely to overlook his absence since, as the only black person in his work group, he "stood out like a raisin in a bowl of rice." 86 Similarly, Everett Howell was convicted of a robbery despite half a dozen alibi witnesses, including a doctor whom he had gone to see at the very time of the robbery in a town seventy miles away and a policeman who had seen him on his way to the doctor's office. ${ }^{87}$

These examples do not describe what generally happens. It is possible, perhaps likely, that few juries believe witnesses who say that they can identify masked criminals and that most suspects with iron-clad alibis are acquitted or never brought to trial. But these examples do illustrate what can happen: some witnesses believe they are capable of impossible feats of identification, and some juries will convict even on the basis of plainly incredible identifications or will choose the identification testimony of strangers over virtually any evidence to the contrary. ${ }^{88}$

84 Borchard, supra note 50, at 176-80 (Henry Olson).

${ }^{85}$ Id., at 317-20 (Sidney Wood).

${ }^{86}$ San Francisco Examiner, December 4, 1983, at E6, and December 15, 1983, at A4 (Lenell Geter).

87 Borchard, supra note 50, at 100-4 (Everett Howell).

${ }^{88}$ In one very strange case the defendant was convicted of robbery on the testimony of a single eyewitness despite the fact that no other witness to the robbery recognized him, while 


\section{F. The Process of Exoneration}

Evidence of Misidentification. All the stories of this data set describe the evidence that ultimately exonerated the suspect, and they reveal a simple basic pattern: in over three-quarters of all the cases $(106 / 136)$, evidence was eventually discovered that established the identity of the actual criminal. (In twenty-four of these cases other exculpatory evidence also played a role in the exoneration.) In seventy-four cases, over half the total, the actual criminal confessed; in an additional thirty-two cases the actual criminal was arrested or otherwise identified but did not confess, at least not initially. This was the dominant basis of exoneration both before Wade (84 percent) and after (70 percent) and within the post-Wade group among convictions and dismissals alike (68 percent and 71 percent, respectively).

There are many different ways that the actual criminal in a case might be located, but a few general scenarios occur repeatedly. In many of these cases the actual criminal happened to get arrested for another crime and confessed to the crime in question as part of a general program of cooperation with the police; in a related set of cases the actual criminal was arrested for a crime that was clearly a repetition of the one with which the misidentified suspect had been charged. In other cases the real culprit was found after a long investigation by the suspect or others acting in his interests or by the authorities. Finally, there are a surprising number of cases in which the actual criminal acted deliberately to exonerate the suspect who had been misidentified. In some cases a guilty suspect confessed and revealed that his codefendant was innocent, often leading the authorities to his real accomplice; in other cases the actual criminal happened to meet the innocent suspect or to hear of his misfortune, usually while both were in prison; two of the actual criminals deliberately staged reenactments of their original crimes to show that the convicted defendants were innocent (and in one instance got caught in the process), ${ }^{89}$ and one robber said after his arrest that he would have done the same if a misidentified suspect had been convicted at trial. ${ }^{90}$

Physical evidence and alibis were tied for a distant second among the

on the other side ten alibi witnesses (including a traffic policeman) testified that he was elsewhere, seven eyewitnesses to the crime said he was not the robber, and the police officers who had originally arrested him testified that they had apparently made a mistake as a result of the suspect's resemblance to a known fugitive bank robber who was probably the real culprit. Radin, supra note 52, at 203-6 (A. B. Chastain).

${ }^{89}$ Frank \& Frank, supra note 51, at 40-50 (I. L. Southerland and Ovid Mathis); Borchard, supra note 50, at 360-62 (George B. Slyter).

${ }^{90}$ Note 74 supra (Manny Balestrero). 
types of evidence leading to exoneration. Eight suspects were cleared solely on the basis of physical evidence, and such evidence played a role in thirteen other cases. The critical items of physical evidence covered a wide range, but the most common ones were linked to the suspect's body: mismatched fingerprints, blood or semen of the wrong biological type, or, in one case, the absence of a skin graft. Nine suspects were cleared on the basis of alibi evidence alone-three before conviction and six after-and an additional ten were cleared in part by such evidence. It is important to remember, however, that in all the cases in this data set criminal charges were filed against the suspects. It is possible, indeed likely, that physical and alibi evidence play larger roles in screening suspects before charges are filed.

Lie detector evidence figured in a dozen or more cases. One suspect was cleared entirely on the basis of polygraph results, and six others were cleared by such tests in conjunction with other evidence, but this tally underestimates the importance of lie detector evidence since its effects are often indirect. In three additional cases polygraph tests were given to defendants after conviction, and the results encouraged investigations that ultimately produced other exculpatory evidence; in five other cases polygraph results may have played the same supporting role before trial in averting erroneous convictions. On the other hand, at least seven defendants were convicted despite the fact that they passed pretrial polygraph tests. Overall, these data tend to support the general belief that polygraph tests are reasonably, but not highly, accurate: eighteen stories mention that the suspects passed a lie detector test before trial, and an additional five did so after trial, but four innocent suspects failed lie detector tests before trial, and in two cases the results were indeterminate.

Mode of Discovery. Many of the suspects in these cases were exonerated by fortuitous discoveries. In 43 percent of the cases in which the process is described $(52 / 120)$ the actual criminal was discovered independently of any investigation of the charges at issue, typically because he happened to confess after an arrest for a later crime. In the remaining 57 percent of these cases $(68 / 120)$ the suspect was exonerated as a result of a deliberate investigation. About one-third of these investigations (21/68) were conducted entirely by defense attorneys or, less commonly, by private investigators or by the suspects and their families. In six other cases the press played a central role. Over half of these investigations, however (37/68), were conducted-or at least completed-by the police or the prosecutors, but most of these official investigations (particularly those undertaken by prosecutors) were the result of new information that was brought to the attention of the authorities or of pressure from the defendant or from his lawyers, his family, or his friends. 
The major factor that determined the course of the unraveling of the errors in these cases was the position taken by the police and the prosecutors. The law enforcement authorities ultimately came to agree that an error had been committed in almost every one of the cases included here-an inevitable consequence of restricting the data to "undisputed" misidentifications. Their positions at earlier stages, however, were not nearly so uniform and were highly influential. Chance was clearly an important factor in many of these cases, especially those that turned on fortuitous discoveries, but it was not the only ingredient; here, as elsewhere, chance favors the open mind. The discovery of the actual criminal does not automatically exonerate a misidentified suspect. The information must reach the relevant officials (often in a different jurisdiction), and they must believe it and act on it. Police officers and prosecutors who wonder whether they have arrested the right person are more likely to notice evidence that another person may in fact be guilty, and more likely to believe that evidence, than those who entertain no doubts.

On the other hand, these cases contain several remarkable illustrations of how difficult it can be to convince a closed mind. Clifford Shephard, ${ }^{91}$ for example, was erroneously identified as a check forger and sent to prison for nine months in New Jersey in 1935. On his release he was rearrested, convicted of several additional forgeries, and sentenced to another eighteen months in prison. After his second release he was arrested a third time and charged with yet another group of forgeries, but this time an alert grand juror noticed that all the forged checks had been passed while he was in prison. The third set of charges was dismissed, of course, but nothing further was done despite the obvious inference that Shephard had been misidentified from the start. In 1938 Shephard hired a private investigator who managed to identify the real forger, one Edward Sullivan, a man who resembled Shephard and who was known to have passed checks written in an identical hand to those for which. Shephard was convicted. With this new evidence in hand, Shephard applied for a pardon to the New Jersey Board of Pardons, but it was denied. In 1940 he applied again; by then he had located Sullivan, who was in prison on other charges, and had obtained a signed confession from him and a corroborating confession from his wife. Again the pardon was denied. It was not until 1950, after five more petitions to the board of pardons and after a newspaperman had managed to interest the governor in the case, that Shephard was finally pardoned.

At the other extreme there are several cases in which the police or the

91 Frank \& Frank, supra note 51, at 74-78; Radin, supra note 52, at 90-94 (Clifford Shephard). 
prosecutors went to great lengths to clear innocent suspects whom they had originally prosecuted. In one case a police detective was skeptical because a man identified for rape, robbery, and kidnapping "did not act like any other rapist" he had known. ${ }^{92}$ The detective could not get the trial postponed but did get the judge to take early recesses so that he could work on the case, and, while the trial was in progress, he located another man who appeared to have been the actual criminal; charges against the first suspect were dismissed. In another case, at a parole hearing at which he was denied parole after nine years in prison, a convicted murderer talked to the district attorney who had originally prosecuted him. He continued to assert his innocence and told the prosecutor that while in prison he had discovered new evidence pointing to the actual killer. Acting on this information, the prosecutor launched an investigation of the case, which he continued to pursue even after he left the district attorney's office and went into private practice. In four months he established the defendant's innocence and arranged for his release. The defendant was amazed: "The same man who prosecuted me was the only one who would listen to me." 93

Convictions versus Dismissals. On the whole, there are more similarities than differences between those misidentification cases that produced convictions and those that ended in dismissals, at least as far as one can tell from the limited post-Wade data set. In each subset of cases the suspects were initially located by similar means and were exonerated by similar evidence obtained from similar sources. ${ }^{94}$ On a couple of points, however, there were noticeable differences between the two groups.

There are suggestions in the data that the nature of a misidentification case may affect the likelihood of conviction in two ways. First, there were convictions in only 28 percent of the post-Wade cases in which the original suspicion was based solely on the suspect's appearance $(7 / 25)$ compared to 51 percent of all other cases (18/35). Second, ten of the post-

92 Redwood City Tribune, July 25, 1978 (Anthony Pickens).

93 San Francisco Chronicle, March 5, 1981 (Aaron Owens). In another remarkable case a prosecutor first became involved when he successfully opposed the misidentified suspect's habeas corpus petition fourteen years after conviction. Despite his victory in court, the prosecutor started an investigation; after four more years he proved that the prisoner was innocent and secured his release. Frank \& Frank, supra note 51, at 195; Radin, supra note 52, at 125-29 (Roy Eaton).

94 One minor difference in the mode of discovery of the misidentification appears to be a natural reflection of the different formal postures of these cases. The police and the prosecutors as a group were responsible for obtaining the final exculpatory evidence in roughly the same proportion of the conviction cases ( 34 percent) and of the dismissal cases ( 40 percent), but the police conducted the bulk of predismissal investigations, while the prosecutors conducted most of the postconviction investigations. 
Wade cases included evidence of police or prosecutorial misconduct or of blatantly suggestive identification procedures, and seven of these ten cases produced convictions compared to one-third of all other cases (16/ 48). These trends are no more than suggestive, but they make sense. Many law enforcement officers are undoubtedly skeptical of eyewitness identifications; if so, they may be more easily persuaded of a suspect's innocence when he was located by his appearance alone than when he was linked to the crime by some form of circumstantial evidence. This attitude could explain the higher proportion of dismissals among those cases in which the suspect was first located by his appearance. On the other hand, officers or prosecutors who have secured an identification by obviously suggestive means or who have concealed evidence or coerced witnesses are not likely to be open to persuasion. In such cases, dismissals are likely to be rare.

A final factor that may have an effect on the likelihood of conviction is the character of the accused. In thirty of the post-Wade cases it was possible to classify the suspect as having either a "bad"' record (meaning one or more criminal convictions) or a "good" record (meaning that there were explicit references to the suspect's upstanding character or to the absence of any convictions or suspicious conduct); the remaining thirty cases could not be classified. Only 22 percent of the good-character cases ended in conviction (4/17) compared to 58 percent of the bad-character cases (7/12). Again, this trend is weak but sensible: the police and prosecutors are more likely to keep an open mind about the guilt of a suspect and more likely to keep searching for new evidence when he strikes them as an improbable criminal. A minor pattern in the data illustrates this process: four of these suspects were themselves agents of the government-two police officers, an assistant district attorney, and a CIA trainee-and all four were cleared before trial.

Time. One measure of the ordeal of a misidentified suspect-perhaps the most obvious-is the time spent in custody. The range in this measure is enormous: nine suspects spent no time at all in custody, while four others spent over fifteen years. Not surprisingly, the most important determinant of time in custody was the outcome of the case, conviction or dismissal. The median time in custody for all cases was between six months and one year. For the dismissals the median was one week, although one-third of the suspects $(10 / 30)$ were in custody for over a month and almost one-quarter (7/30) for over three months. Among the convicted suspects the median time spent in custody was between one and two years. Several of the convicted suspects spent no time in custody because they were freed on bail immediately after arrest and were exonerated without serving any portion of a sentence of imprisonment. Of 
those who were incarcerated, however, only one spent less than a month in custody, while sixteen, one-sixth of the total, were imprisoned for more than five years, including one for nineteen years and one for thirty.

Despite its obvious importance to the suspects, time in custody is an imperfect measure of the duration of a misidentification case since it excludes any period in which the suspect was free on bail or personal recognizance and any time after release from prison or jail but before exoneration. The total time from arrest to exoneration is a useful measure of the consequences to the accused of a misidentification-the unpleasant effects of a serious criminal charge are not restricted to imprisonmentand is the best measure of the rate at which the criminal justice system corrects misidentifications. In Table 2 the cases in this data set are sorted according to outcome and divided by time from arrest to exoneration into nine groups that form a rough geometric scale. The median time from arrest to exoneration for all cases was about one year. For the dismissals the median was between three and six months and for the convictions between one and two years. ${ }^{95}$

The pre-Wade sample within this data set is biased on the duration of the cases since it consists almost entirely of misidentifications that produced convictions. The post-Wade sample, by contrast, has no clear bias on this dimension and can be used to estimate, roughly, the rate at which misidentifications are corrected.$^{96}$ An examination of these cases shows a clear overall pattern: the longer the time from arrest, the less likely it was that a misidentification would be rectified in any given period of time. Many misidentifications, 15 percent of the total, were corrected within a week of arrest-that is, immediately following the identification of the accused as the criminal. The rate of detection of a misidentification dropped sharply after the first week, by a factor of about ten, and continued to decline (but more slowly) over the period up to two years after arrest, a period that includes, for almost all cases, the entire pretrial investigation and the trial, if any. Finally, the rate of exoneration dropped

\footnotetext{
95 There were no conspicuous differences between the cases that were cleared quickly and those that were cleared slowly either in the type of evidence that exonerated the suspect or in the mode of discovery of that evidence, with one possible exception: Cases in which the suspect was exonerated on the basis of physical evidence seem to take longer than the rest. Half of all the cases lasted a year or less, but eight of the eleven cases in which the suspect was exonerated primarily on the basis of physical evidence lasted over a year, and six lasted over two years. However, there are too few cases in this category to draw any conclusions from this pattern.

\%6 Even the post-Wade sample may be slightly skewed on duration since cases that are dismissed quickly may be less likely to appear in the media than those that last longer.
} 
TABLE 2

Time from ArRest to Exoneration

\begin{tabular}{lccc}
\hline \hline Time & Dismissals & Convictions & All Cases \\
\hline Up to 1 week & 8 & 0 & 8 \\
1 week-1 month & 3 & 1 & 4 \\
1-3 months & 4 & 5 & 9 \\
3-6 months & 4 & 15 & 19 \\
6 months-1 year & 6 & 15 & 21 \\
1-2 years & 7 & 18 & 25 \\
2-5 years & 1 & 17 & 18 \\
5-10 years & 0 & 12 & 12 \\
Over 10 years & 0 & 9 & 9 \\
$\quad$ Total & 33 & 92 & 125 \\
\hline
\end{tabular}

sharply once more, by a further factor of about ten, in the period beyond two years after arrest. ${ }^{97}$

\section{G. Historical Trends}

The fact that eyewitness identification has received so much attention in the past two decades suggests a natural question: Has the nature of the problem changed over time? It is possible to investigate this question, if only imperfectly, by comparing the pre-Wade cases in this data set with those that occurred after Wade. In most respects these two sets of cases appear to be similar both in the origin of the misidentifications and in their resolution, but in three areas there are substantial differences: the crimes charged, the identification procedures, and the evidence of innocence.

Crimes. As I have noted, the vast majority of these cases involved crimes of violence. This basic pattern applies both before and after Wade. However, virtually all of the handful of misidentifications in cases of nonviolent crimes $(14 / 15)^{98}$ occurred before Wade. This pattern is due entirely to a discrepancy in a single category of crimes: forgery, check fraud, and other "bad-paper" crimes. There were eleven such cases in the pre-Wade set-15 percent of the total number of cases in that period (11/75) and 79 percent of the nonviolent crimes cases (11/14) - and no such cases after Wade. Within the general category of violent crime, there is a second historical discrepancy: only three of the pre-Wade cases (4

\footnotetext{
97 The rates for the periods beyond two years after arrest are probably underestimates since in some of these cases the crimes occurred within two to five years of the data collection.

98 In one additional case of a misidentification for a nonviolent crime (check forgery) it could not be determined whether the crime occurred before or after the Wade decision.
} 
percent of the total) involved a rape compared to twenty-four of the postWade cases (40 percent of all cases in that period). Both of these changes probably reflect general historical trends in felony dispositions: convictions for forgery and related crimes have become far less common since 1960 , while rape convictions have become far more common. ${ }^{99}$

Suggestiveness. Pretrial identification procedures can be suggestive in many ways from the very obvious to the very subtle. On the whole these data contain too little information to permit an evaluation of the suggestiveness of the specific confrontations at which the suspects were identified, but it is possible to tell something about overall historical trends by examining two rough measures of suggestiveness.

First, for seventy-three of these 136 cases it was possible to determine with a fair degree of confidence whether a pretrial lineup, either physical or photographic, was ever used to identify the defendant. The mere occurrence of a lineup does not, of course, guarantee the fairness of the identification procedure. ${ }^{100}$ Some of the lineups described in these stories were obviously suggestive, ${ }^{101}$ and in some cases lineups were used in conjunction with other suggestive identification procedures. ${ }^{102}$ In general, however, the use of a lineup does indicate at least a minimal level of concern about the possible suggestiveness of identification procedures. The data seem to show a clear historical trend. The use of a lineup was apparent in thirty of the sixty post-Wade cases (50 percent of the total), while there were only four post-Wade cases ( 7 percent) in which it was clear that a lineup had not been used. Among the pre-Wade cases the pattern was the reverse. There were only thirteen out of seventy-five cases ( 17 percent) in which it could be determined that a lineup had been used and twenty-six cases (35 percent) in which it was apparent that no lineup had been employed.

\footnotetext{
99 California prison statistics, for example, show that from 1960 to 1980 the proportion of "male felons newly received from court" who had been convicted on forgery or bad-check charges declined from 20.1 percent to 3.1 percent, while the proportion of convicted rapists increased from 1.9 percent to 5.3 percent. California Dep't Justice, supra note 7 , at 22 .

100 See, for example, note 41 supra.

101 In one case, for example, a murder suspect (who ultimately spent thirty years in prison) was picked out of a lineup but only after the police pointed him out to the only eyewitness and told her that he was the killer. Loftus, supra note 2, at 178-79 (Charles Clark). Another suspect was picked out of a lineup that included only two other people, one of them a policeman known to the eyewitness. Ferguson \& Miller, supra note 52, at 129-30 (Herbert Smith).

${ }^{102}$ One rape victim, for example, failed to pick the suspect from a lineup but later identified him in court-after a forty-five-minute conversation with the police. He was convicted and spent two years in custody. Los Angeles Times, November 14, 1980; Peninsula Times Tribune, November 13, 1980 (Keith A. Hart).
} 
Second, some of the stories revealed that the suspect had been identified by extraordinarily suggestive means. For example, two robbery suspects were placed in "show-ups"-one-on-one confrontations with eyewitnesses-in which they were required to put on clothing similar to that worn by the actual robbers, pull caps down over their faces, and, in effect, act out the robberies. ${ }^{103}$ In another case a murder suspect was singled out from behind a one-way mirror. ${ }^{104}$ Twenty of the pre-Wade stories (27 percent of the total) mention some obvious suggestive feature of the identification procedures, while only seven post-Wade stories (12 percent) refer to similar suggestive elements.

These are, of course, highly imperfect measures of the suggestiveness of police identification procedures. The data are limited and the categories imprecise. Nonetheless there is more than a hint that something has changed, especially since two different measures of suggestiveness point in the same direction. The cause of this change is less certain; it may simply reflect more general awareness about the dangers of eyewitness identification. Very likely, however, the Supreme Court's eyewitness identification cases are responsible for much of the improvement, both directly (because they changed the rules that govern the use of identification evidence at trial) and indirectly (because they made police officers, prosecutors, and judges more sensitive to the problem). A casual review of police literature on eyewitness identification certainly suggests that the Supreme Court cases had some effect. For example, two weeks after Wade was announced, the New York City Police Department issued an order "To All Commands" on the subject of lineups that began, "On June 12 , 1967, the United States Supreme Court in three cases indicated that certain procedural safeguards must be established before law enforcement officers submit a person in custody to a 'lineup.' " 105 It would be a mistake, of course, to assume that such pronouncements are always obeyed, but it would also be wrong to suppose that they had no effect at all.

103 Borchard, supra note 50, at 328 (J. Anthony Barbera), and at 64 (Floyd Flood). See also id. at 159 (Clarence McKinney) (police officer-witness identified suspect after the suspect put on a coat and hat similar to those worn by the robber, the lights were turned out, and the officer flashed his light in the suspect's face); N.Y. Times, September 29, 1982, at 14A (anonymous) (rape victim confronted with suspect at hospital asked to be taken to a local precinct so she could see him in a dark room).

104 Note 78 supra (George Reissfelder).

105 Reproduced in Ringel, supra note 5, at 113-14. Similarly, the Model Rules on Eyewitness Identification (Police Foundation, supra note 22) state that " $[\mathrm{m}]$ uch of the policy underlying these Rules is derived from the decisions of the Supreme Court in [Kirby, Simmons, and Wade]" (at 17). 
Confessions. As we have seen, most of the suspects in these cases were exonerated by the use of information about the actual criminal, but it was not always the same type of information. In 69 percent of the preWade cases $(52 / 75)$ the actual criminal confessed, but only 35 percent of the post-Wade suspects $(21 / 60)$ had the benefit of such confessions. ${ }^{106}$ This deficit among the post-Wade cases is made up primarily by an increase in the proportion of cases in which the suspect was exonerated by information about the actual criminal in the absence of a confession or by the use of physical evidence. There has been a corresponding change in the mode of discovery of the exculpatory evidence. The proportion of cases in which the exonerating evidence was obtained by the fortuitous discovery of the actual criminal (typically as a result of a confession) dropped from 53 percent before Wade $(36 / 68)$ to 33 percent after Wade (17/52); most of this difference is made up by a parallel increase-from 21 percent $(14 / 68)$ to 37 percent (19/52)-in the proportion of suspects who were cleared as a result of deliberate investigations by the police and prosecutors.

As with suggestiveness, it is easier to describe this change than to explain it. It may be, as I have suggested, that law enforcement officers have become more sensitive to the dangers of eyewitness testimony and more energetic in investigating possible eyewitness misidentifications, even in the absence of exonerating confessions. It seems likely, however, that at least part of the difference is due to a change in the behavior of criminals: confessions seem to have become less popular, perhaps as a result of changes in the law.

The 1967 trilogy of Supreme Court identification cases was decided toward the end of a period of dramatic development in the due process rules governing criminal procedure. Several cases from that period bear on this issue. In 1963 the Supreme Court decided Gideon v. Wainwright, ${ }^{107}$ holding that every indigent person accused of a serious crime is entitled to appointed counsel; in Jackson v. Denno ${ }^{108}$ in 1964 the Court reinforced the prohibition against the use of involuntary confessions; and in 1966, in the most controversial criminal case of that era, Miranda $v$. Arizona,${ }^{109}$ the Court prohibited prosecutors from using any statement obtained from a suspect in a custodial interrogation unless the suspect was warned of his right to remain silent and his right to retained or

\footnotetext{
106 Among the post-Wade cases, similar proportions of conviction cases and dismissal cases were cleared by the actual criminal's confession.

107372 U.S. 335 (1963); see also Argersinger v. Hamlin, 407 U.S. 25 (1972).

108378 U.S. 368 (1964).

109384 U.S. 436 (1966).
} 
appointed counsel and unless he waived those rights. One would expect that these decisions, if they had any effect, would reduce the number of confessions that the police obtain from criminals, but it is difficult to evaluate their actual impact on the conduct of criminal investigations. The best data on the issue can be found in several studies on the effects of the Miranda decision, and they are inconclusive. ${ }^{110}$ It seems that the police generally comply with the letter, if not the spirit, of Miranda and that this may result in some reduction in the number of confessions but that the devastating consequences predicted by some critics of that decision ${ }^{111}$ have not materialized.

Whatever the cause-Miranda, Gideon, the entire Warren Court criminal procedure jurisprudence, or other less conspicuous historical processes-it is difficult to read these misidentification stories without concluding that a significant change took place sometime between the mid-1950s and the early 1970s. One pre-Wade story, for example, gives a description of the suspect's exoneration that is typical of that period: the actual criminal was arrested on an unrelated charge and, "[a]fter being held in custody for a day or two, she confessed to the perpetration of all the crimes charged to [the misidentified suspect]." 112 By contrast, a story on the unraveling of a well-publicized recent misidentification case reports that the press was excluded from the arraignment of the actual criminal "after [his] public defender attorney protested, saying that identification is a key factor in the case and that a newspaper picture could prejudice the witnesses who will be called to a police lineup or to testify during a trial.",113

\section{H. Major Patterns}

To summarize, the strongest patterns in this set of cases are these: (1) More often than not, a misidentified defendant was originally suspected because of his appearance. (2) A misidentified defendant is more likely to be cleared before his case comes to trial than after. (3) If he is not ex-

\footnotetext{
110 See Project, Interrogations in New Haven: The Impact of Miranda, 76 Yale L. J. 1519 (1967); Richard H. Seeburger \& R. Stanton Wettick, Jr., Miranda in Pittsburgh: A Statistical Study, 29 U. Pitt. L. Rev. 1 (1967); John Griffiths \& Richard E. Ayres, A Postscript to the Miranda Project: Interrogations of Draft Protesters, 77 Yale L. J. 300 (1967); Richard J. Medalie, Leonard Zeitz, \& Paul Alexander, Custodial Police Interrogation in Our Nation's Capitol: The Attempt to Implement Miranda, 66 Mich. L. Rev. 1347 (1968); Lawrence S. Leiken, Interrogation in Colorado: The Implementation of Miranda, 47 Den. L. J. 1 (1970); Otis H. Stephens, Jr., The Supreme Court and Confessions of Guilt 179 (1973).

111 See, for example, statements reported in Stephens, supra note 110, at 165-66.

112 Borchard, supra note 50, at 331 (Mary Berner).

113 Seattle Post-Intelligencer, July 4, 1981 (Steve Titus).
} 
onerated before trial, a misidentified defendant will almost certainly go to trial rather than plead guilty, even in return for an attractive plea bargain. (4) A misidentified defendant who is convicted at trial may still be exonerated, but the chances decrease over time. (5) The most common basis for exoneration is the capture of the actual criminal (typically a fortuitous event), but a fair number of misidentified defendants are also cleared by physical or alibi evidence. (6) In many cases the fate of a misidentified defendant depends on luck.

\section{IMPLICATIONS}

\section{A. Proof of Criminal Guilt}

In theory, trial by jury is the essential mechanism for determining the historical facts of a case, and the pretrial stages of investigation and negotiation are essentially anticipatory-efforts to prepare for and to predict the outcome of that ultimate event. Under this scheme the accuracy of adjudications of guilt depends on the ability of juries to determine facts correctly and, in particular, to avoid erroneous convictions.

This paper is an attempt to study the relative infrequency of erroneous convictions caused by eyewitness misidentification. I do not claim to know the actual rate of judicial misidentifications, and my argument does not depend on the magnitude of that rate. Rather 1 claim that the rate of errors, whatever it is, is far lower than could possibly be achieved by reliance on the eyewitness evidence that is used to obtain so many convictions or by reliance on the formal mechanisms of proof that are embodied in the criminal jury trial. In fact, juries are not particularly good at evaluating eyewitness testimony and determining its accuracy and are not exceptionally careful about convicting defendants on the basis of eyewitness evidence. If they return few erroneous convictions it is because they are given few opportunities to judge innocent defendants. In the usual case the actual determination of guilt occurs much earlier and in less formal settings, at a police precinct or in a district attorney's office, and is based on an investigation that is not necessarily conducted in anticipation of a trial. A jury trial is a risk, a potentially catastrophic event, that may be imposed on a defendant who fails to clear himself or to come to terms on a bargained plea of guilt.

The Causes of Judicial Misidentification. At root, the accuracy of the determination of identity in criminal cases depends on redundance. In most cases in which the identity of the criminal is in dispute there are multiple, independent sources of information pointing to a single suspect. Errors can occur in such cases (a few of the misidentifications that are 
collected here fit that mold), but they are rare. When the identification depends on a single type of evidence, however, mistakes are much more likely.

The redundance that counts is not between one eyewitness and another but between different types of evidence of identity. Obviously, a second eyewitness adds something to our confidence in the accuracy of an identification, provided that the second identification was not influenced by the first. But a multiplicity of eyewitnesses is no guarantee of accuracy; among the misidentified suspects discussed here, 60 percent were identified by two or more eyewitnesses. In some of these cases suggestive identification procedures may have destroyed the independence of the identifications by different witnesses, but it does not seem likely that suggestiveness alone could explain such a high proportion of multiplewitness errors. Moreover, experimental evidence indicates that different eyewitnesses will often converge on a single misidentified suspect. ${ }^{114}$ This is not surprising. The most that can be established by the eyewitness testimony of strangers, whatever their number, is that a suspect looks very much like the criminal. In the usual case this is a necessary condition for an accurate identification. ${ }^{115}$ For this reason, eyewitness testimony that the suspect is not the criminal (as opposed to mere uncertainty) should be taken seriously. But even a strong resemblance to the criminal is not sufficient to prove identity, and in many cases eyewitness identifications actually prove a good deal less-merely that the suspect looked more like the criminal than did any other available choice. In the absence of corroborating evidence of a different sort, errors will be common.

Investigation versus Prosecution. In theory, our common-law system of criminal justice is adversarial, a system that is often contrasted to the investigatory, or "inquisitorial," method of adjudication that is used in civil law countries. ${ }^{116}$ The adversarial system is not restricted to litigation but can include bargaining between adversaries, for example, the bargain-

\footnotetext{
114 Dunning et al., supra note 24.

115 In some cases the appearance of the criminal will have changed because he was disguised at the time of the crime, or because he deliberately changed what he could change later, or because of illness, injury, or the passage of time.

116 See Mirjan Damaska, Presentation of Evidence and Factfinding Precision, $123 \mathrm{U}$. Pa. L. Rev. 1083 (1975); Mirjan Damaska, Evidentiary Barriers to Conviction and Two Models of Criminal Procedure: A Comparative Study, 121 U. Pa. L. Rev. 506 (1973). In practice, criminal procedure in Continental civil law countries may be more adversarial than the formal description of the inquisitorial system suggests-see Abraham S. Goldstein \& Martin Marcus, The Myth of Judicial Supervision in Three "Inquisitional" Systems: France, Italy and Germany, 87 Yale L. J. 240 (1977)-but that has no particular implications for this discussion.
} 
ing that takes place in our criminal courts over the terms of punishment for defendants who are assumed to be guilty. The defining feature of the adversarial system is that evidence is found and presented primarily by the parties and that when facts are in dispute they are resolved by a passive judicial fact finder. By contrast, the essential actor in the investigatory system is the magistrate (or a functional equivalent), a neutral governmental official whose duties include both investigation and adjudication.

The actual process of criminal law enforcement in our system is a hybrid, an adversarial limb grafted onto an investigatory body. The police and the prosecutor begin their work on a case in the role of quasi-judicial investigators. They attempt to uncover the facts, determine the truth, and bring the criminal to punishment. Normally, the basic outcome of a case is determined within this investigatory mode: failure if the criminal is not found, success if he is found and pleads guilty. Successes, of course, are not all equivalent. There may be important questions about the exact charges or the sentence, and there is often room for adversarial advocacy in the negotiations that settle those questions. But the inevitability of a guilty plea is apparent at the time of arrest in many if not most prosecutions. Sometimes, however, this process breaks down. Typically this happens when a defendant is reluctant or unwilling to plea bargain, either because he believes the outcome of the trial can be no worse than the bargain offered, or because he is willing to risk conviction and a worse sentence for the chance of an acquittal, or because he is not rational (as the system defines rationality), or because he is innocent. When such an impasse is reached the case moves into the formal process of litigation, and the police and prosecutor shift in earnest into adversarial roles. The timing of this shift will vary from case to case, as will the clarity of the line that separates these two types of professional roles, but both stages will occur in any criminal case that ends in trial: investigation first, prosecution second.

The Initial Identification: Suggestiveness and the Absence of Corroboration. The first step in a criminal investigation is the initial identification of the suspect. Two types of identification problems can occur at this stage, one that is widely recognized and one that has gone unnoticed. Either can increase the probability of errors by eliminating the usual independent corroboration of eyewitness testimony.

The first type of problem is caused by suggestive confrontations between eyewitnesses and suspects. The dangers of suggestive identification procedures are well known and severe: if the police suggest the identification to a witness, the eyewitness testimony may add nothing to the information the police already had. It is impossible to estimate the 
actual effect of suggestiveness from the data collected here, but these cases seem to indicate that suggestiveness, while dangerous, is a less influential cause of judicial errors than the legal and psychological literature might lead one to believe. This is to be expected since this literature does not discuss the fact that the police and prosecutors generally have other evidence of identity, often inadmissible evidence, that may be more reliable than the eyewitness evidence would be even in the absence of suggestiveness.

The second type of problem that can occur at the initial identification presents a more basic danger. Where the suspect first comes to police attention because of his appearance, there simply may be no information implicating him beyond that which eyewitness identification can provide in any event-the fact that his appearance resembles that of the criminal. As expected, these cases are uncommonly prone to errors: 60 percent of the misidentifications gathered here fall in this group. A clear and common example of this type of problem case is the "spontaneous identification," a case in which an eyewitness first spots the suspect in an unplanned encounter. Yet despite the fact that many reported misidentifications originated in this manner (including one of the most famous), ${ }^{117}$ previous discussions of eyewitness identification have missed the danger of this form of identification entirely. On the contrary, several authorsfocusing solely on the fact that suggestiveness is not possible in spontaneous encounters-have stated that this is "the most reliable type of identification.", 118

It is easy to see why psychologists have overlooked the importance of the basis for the initial suspicion against a suspect. They have been interested primarily in the cognitive task of eyewitness identification and in the social and situational factors that influence that task and not in the process for determining the identity of criminals. Courts and legal commentators may have been influenced by this psychological perspective, but that alone does not explain why, in an area that has received such detailed attention, this aspect of the process has been so thoroughly ignored. The major reason, I think, is ideological. The legal rules governing the use of eyewitness identification evidence were developed as due process protec-

117 See Life, June 29, 1953, at 97-107 (Manny Balestrero). In 1956 this case became the basis for a full-length feature film entitled The Wrong Man, which was directed by Alfred Hitchcock and starred Henry Fonda. See also Frank O'Connor, "That's the Man': A Sobering Study of Eyewitness Identification and the Polygraph, 49 St. John's L. Rev. 1 (1974).

118 Wall, supra note 1 , at $181 \mathrm{n} .2$; see also, for example, Ringel, supra note 5, at 68; Comment, Possible Identification Procedural Safeguards against Mistaken Identification by Eyewitnesses, 2 U.C.L.A. L. Rev. 552, 556-57 (1955) (Edward Lasker). 
tions for the benefit of the accused, and, as a result, the legal debate on this topic has been dominated by what Herbert Packer called the Due Process Model of criminal law. ${ }^{119}$ The problem that I have identified here is difficult even to formulate and impossible to solve within the Due Process Model. For one thing, it would be awkward to describe the absence of an independent basis for suspicion as a problem in identification cases given that some of the most useful independent grounds for suspicion consist of information that (from the point of view of due process) must never be used to determine guilt: inadmissible hearsay and illegally obtained evidence.

More important, the due process perspective is necessarily adversarial; it requires a specific citizen whose rights must be protected as well as a state whose agents may fail to do so. One of the major impulses behind the due process perspective is the desire to avoid wrongful convictions, but this adversarial assumption limits the reach of this concern. The presence of counsel for accused at lineups can be regulated by due process rules in an attempt to improve the accuracy of eyewitness identifications since, by the time a lineup is constructed, there is a suspect whose rights are at issue. By contrast, it is quite possible that a larger number of errors could be avoided if the police were consistently conscientious in collecting fingerprints and physical evidence at the scene of violent crimes (as, unfortunately, they are not), ${ }^{120}$ but it is hard to see how this investigative failure could be described as a violation of due process since it typically occurs before the police have any idea whose rights might be affected by their omissions. The methods of police investigation can (in theory) be regulated at any point to the extent that they affect the rights of citizens, as citizens, to privacy. In addition, once a suspect has been identified, however tentatively, due process may regulate any official actions that affect him-interrogation, arrest, etcetera. In particular, a suspect cannot be arrested or held for trial without evidence amounting to "probable cause" to believe that he is guilty of a crime; in an identification case, this evidence is usually supplied by eyewitness testimony. But the content of the information that brought the suspect to mind in the first place and that

11 Herbert Packer, The Limits of the Criminal Sanction 149-246 (1968).

120 See Michael Saks \& Richard VanDuizard, The Use of Scientific Evidence in Litigation $37-38,88$ (1983). A rape case from New York provides an ironic example of this problem. The investigating officers retrieved the sheets from the bed where the rape occurred only after the victim insisted that they do so; later, an analysis of the semen on the sheets was instrumental in exonerating the suspect whom the victim had mistakenly identified, but the victim continued to insist that he was guilty and publicly excoriated the police and prosecutors for dismissing the charges against him. N.Y. Times, August 28, 1982, and September 20, 1982, at A14 (anonymous). 
made him the subject of the identification procedure cannot be regulated directly by due process rules because, by definition, it was obtained at a time when there was no suspect to protect.

Pretrial Proceedings. While the initial task of a criminal case-locating the suspect-has no adversarial component, the next phase contains elements of both types of proceedings. At this point formal charges have been filed, the defendant is generally represented by a lawyer, and both sides must prepare for plea negotiations and for the possibility of a trial. At the same time, the prosecutor retains the role of a quasi-judicial investigator whose highest commitment is to justice, and the defendant may be able to obtain a dismissal by satisfying the prosecutor of his innocence. In other words, the defendant may deal with the prosecutor in either (or conceivably both) of two distinct roles: bargaining with an adversary or pleading to a magistrate. In both roles, the position of the prosecutor is made stronger, and that of the defendant more vulnerable, by the availability of eyewitness identification testimony.

Bargaining in the Shadow of the Law. ${ }^{121}$ Consider a case in which a defendant was identified to the police by a reliable anonymous informant (or by illegally seized evidence, or by an inadmissible confession of a codefendant) and was then unwilling to tell the authorities anything about his actions at the time of the crime. On these facts the authorities may have a strong basis to believe that the defendant is guilty (in some cases a conclusive basis), but if that is all the evidence they have the defendant could not be brought to trial let alone convicted. However, if the authorities add a single eyewitness identification to their case, even one obtained under suggestive circumstances, the defendant could be prosecuted and might well be convicted despite the limited value of the eyewitness testimony itself. In short, eyewitness testimony can make it possible for a prosecutor to get a conviction with unreliable evidence that she could not have gotten with inadmissible evidence. In most cases those convicted will in fact be guilty, and in most cases these defendants will not insist on a trial but will negotiate a deal. Because eyewitness evidence is almost always legally sufficient to support a conviction, and because some juries seem to believe even shaky eyewitness identifications, the availability of an eyewitness, any eyewitness, is one of the more valuable plea-bargaining chips a prosecutor can possess.

Pleading in the Shadow of the Law. A guilty defendant may be induced to plea bargain by the possibility of a trial at which he will be identified by one or several eyewitnesses; but what about an innocent

121 See Robert H. Mnookin and Lewis Kornhauser, Bargaining in the Shadow of the Law, 88 Yale L. J. 950 (1979). 
defendant, one who has been misidentified? He will not want to go to trial-the risk is too great-and he certainly will not want to plead guilty. Eventually, he may be forced to one or another of these options, most likely a trial, but his first move will be to attempt to convince the prosecutor that he is innocent. A defendant cannot bargain for a dismissal on the grounds of innocence; unlike plea bargaining, he has nothing to offer in return. Rather, he must persuade the prosecutor that she has made a magisterial error; he must engage in what might be called (to paraphrase Mnookin and Kornhauser's well-known phrase) ${ }^{122}$ "pleading in the shadow of the law." The case of United States $v$. Del Monico ${ }^{123}$ is a good illustration.

On October 8, 1962, John Stinson, a banker in Evansville, Indiana, was robbed at gunpoint by a strange man. Six months later Charles Del Monico was indicted in Los Angeles for extortion from an Evansville native, and Stinson saw his picture in a local newspaper. Stinson recognized the photograph as the gunman who robbed him, as did others at the bank. Eventually, in March 1964, Del Monico-who in the meantime had been sentenced to five years in prison on the extortion charge-was arraigned for the Indiana bank robbery on the basis of this eyewitness evidence; by then he had been identified by six witnesses. Del Monico, a convicted extortionist and the son of a reputed gangster, denied that he had ever been in Indiana prior to his arraignment and produced two reputable alibi witnesses who said that he had been in Miami Beach at the time of the robbery. Del Monico's lawyer, Edward Bennet Williams, asked his client to take a polygraph test; the polygrapher said he was innocent. Williams presented this evidence to the Justice Department, but they were not interested. Undaunted, Williams obtained two more polygraph tests and two narcoanalysis (truth serum) tests, all from well-known institutions, all clearing his client. Finally, the Justice Department asked Del Monico to submit to a test by its own narcoanalyst; he did, and he passed, and on the eve of trial U.S. Attorney Richard Stein dismissed the indictment. Faced with a furious response from the victims of the robbery, Stein agreed that Del Monico would probably have been convicted at trial but said that he was persuaded of his innocence by the mass of inadmissible evidence and by the lack of corroboration of the eyewitness testimony: "We were afraid of a miscarriage of justice." 124

In his book the Limits of the Criminal Sanction, Herbert Packer dis-

122 Id.

${ }^{123}$ Ferguson \& Miller, supra note 52, at 115-17; Newsweek, February 1965; Lloyd L. Weintraub, Criminal Process, 644-46 (3d ed. 1978) (Charles Del Monico).

124 Ferguson \& Miller, supra note 52, at 117. 
cusses two modes of fact-finding in criminal cases: "informal factfinding" by the police and prosecutors and "adjudicative fact-finding" by the courts. ${ }^{125}$ The former mode is favored by the advocates of the Crime Control Model of criminal law, in large part because they believe it promotes the efficiency of the system, and the latter is favored by the advocates of the Due Process Model, in part because they believe it improves the accuracy of the fact-finding. Packer's own position, to the extent that he discusses the issue, is that "informal fact-finding will make some mistakes that can be remedied if backed up by adjudicative fact-finding."126 The actual relation between these two modes of determining guilt seems to be more interesting and more complex, at least in the context of eyewitness identification. Formal adjudication operates less as a backup to catch prosecutorial errors than as a threat that drives defendants to plead their innocence to the prosecuting authority in the first place rather than face their day in court.

Any defendent who has been identified by an eyewitness faces (at a minimum) a substantial risk of conviction at trial, even if he is innocent. Given this risk, an innocent defendant is likely to try to convince the prosecutor to dismiss the case and thus avoid ever facing a jury. Many defendants would do this-even though they might sacrifice some tactical advantages should the case ultimately go to trial-simply to take advantage of one of only two chances they will have to avoid conviction. But often there is more to it than that. For one thing the defendant may be able to use evidence before the prosecutor that he could not use in court, for example, polygraph evidence. More important, some prosecutors, perhaps most, are more skeptical of eyewitness identification evidence than the juries to whom they present it. ${ }^{127}$ One can imagine the position of a particularly unscrupulous prosecutor: "Well, I don't know about these eyewitness identifications myself, but I think the jury would believe them, so if you're innocent you'd better prove it to me."' Even a prosecutor who is not so explicit or so self-conscious will generally find out before trial whether the defendant in an identification case can produce credible evidence of his innocence; if he cannot the prosecutor will regard that (correctly) as further evidence of guilt. On the other hand, when a prosecution is pursued despite strong affirmative evidence of innocence, the risk of

125 Packer, supra note 119 , at 158-73.

126 Id. at 164.

${ }^{127}$ In one misidentification case, for example, the prosecutor said that "[i]t's always scary to go to trial with only an identification." United Press International, June 18, 1984 (Maurice Williams). In another case the prosecutor described the use of uncertain eyewitness identification as "a flaw in the system." Associated Press, January 6, 1984 (Jerome Mills). 
error is increased, a fact that is apparent from the many cases in which erroneous convictions were returned after prosecutors ignored solid alibi evidence or neglected to conduct decent investigations. ${ }^{128}$

The informal mode of fact-finding differs from the formal mode in more than time and place. There are no evidentiary or constitutional restrictions on the information that may be considered. Once the defendant has been charged the burden is on him to prove his innocence-he is, as a practical matter, presumed guilty, ${ }^{129}$ and a failure to produce evidence or to explain conduct will certainly be used against him. These differences may be disturbing to advocates of due process, but they do not make informal fact-finding less accurate. Quite the contrary, they make a range of information available that can improve the factual accuracy of the informal process, provided that the prosecutor does her job conscientiously. In short, the relative inaccuracy of formal adjudication not only forces defendants to rely on informal fact-finding but, by securing their cooperation, simultaneously makes the informal process more accurate in its results.

\section{B. Reducing Errors}

There are two categories of changes in current practice that could reduce the number of erroneous convictions in identification cases: (1) changes in the types of information that may, or should, or must be gathered and used in determining guilt; and (2) changes in the standards that are used to evaluate that information. I will discuss both types of potential remedies as they might be applied at three stages of the criminal proceedings: trial, the pretrial investigation, and the decision to prosecute.

Procedures at Trial. ${ }^{130}$ The major existing rules on eyewitness identification evidence at trial limit the use of identifications that were obtained under suggestive circumstances. These restrictions are useful since suggestiveness is one of the two primary causes of identification errors, but their value has diminished with each successive Supreme Court opinion since 1968. The right to counsel at lineups that was adopted in Wade was all but abolished in Kirby and $A s h$, and the due process exclusion of suggestive identifications that originated in Stovall v. Denno was greatly

\footnotetext{
128 See, for example, notes 86, 87, and 91 supra and accompanying text. See also Jackson v. Fogg, 589 F.2d 108 (2d Cir. 1978) (criticizing the police for incompetent investigation in a robbery-murder case that turned on eyewitness identifications).

129 For a discussion of the pragmatic "presumption of guilt" in criminal cases, see Packer, supra note 119 , at 160-62.

${ }^{130}$ See notes 28-41 supra and accompanying text.
} 
diluted by Biggers and Brathwaite. These more recent cases have had the unfortunate effect of permitting wider use of suggestive identifications than the original rules that were announced in 1967.

The current constitutional restrictions on eyewitness identification evidence are more misdirected than lax. The only substantial restriction that is still in force is the Biggers requirement that the identification by an eyewitness be "reliable," taking into account the "totality of the circumstances." 131 This rule assumes that courts have the ability to determine after the fact which eyewitnesses are likely to have been inaccurate-a heroic assumption, to say the least, and an inefficient method of implementing any policy, especially in a system in which most determinations of guilt or innocence are effectively made before trial. It also restricts courts to an extreme remedy since an "unreliable" eyewitness may not identify the defendant at all, which often leaves no useable evidence of identity.

The major useful effect that procedural rules at trial could have is to prevent the police from permanently degrading the quality of the available evidence by deterring them from using suggestive identification procedures in the first place. To the extent that police investigations can ever be shaped by exclusionary rules, that deterrent effect will be best achieved by clear rules, predictably enforced, with clear consequences. The rules in Wade and Stovall, as they were commonly understood before 1972, fit this bill. They had clear consequences: an out-of-court identification that was obtained at any lineup where there was no counsel for the accused or that was the product of an unnecessarily suggestive identification procedure could not be admitted in evidence. At the same time, these rules permitted the prosecutor to establish an independent basis for admitting an in-court identification in evidence even if a violation occurred, thereby limiting the drastic consequences of the exclusionary remedy and reducing the temptation to judges to circumvent the rules or to ignore them altogether.

The second common cause of misidentifications is the absence of corroborations of an eyewitness identification by non-eyewitness evidence. In theory this problem could be attacked in two ways: (1) by removing restrictions on the admission of evidence in order to inform juries better about the presence of corroboration, and (2) by changing the weight that juries are permitted to give to eyewitness identification testimony.

Under current practice a case in which the defendant was first mentioned to the police by a reliable confidential informant will look no stronger to the jury than one in which he was simply picked out of a mug book;

131 Neil v. Biggers, 409 U.S. 188, 199 (1972). 
indeed, the first case may look weaker since only in the mug-book case will the process of discovery be described. Nonetheless, it would be unwise to admit this corroborating evidence or the other types of corroborating evidence now commonly excluded. There are strong social policies behind the rules against the use of hearsay, coerced confessions, illegal searches and seizures, and the defendant's failure to explain his conduct, and there is little reason to change them in this context since it is unlikely that the number of erroneous convictions would be reduced. Some of the most useful types of corroboration-conspicuously, hearsay from confidential informants-are easy to fake. Once all the players have learned the value of such evidence, some police officers would inevitably succumb to that temptation. Even if this happens only infrequently, it would greatly reduce (if not reverse) any possible benefits of using such evidence: the detrimental effect of fictional corroboration would be powerful in the few cases in which it is used, while the information now lost by excluding real corroboration touches a larger class of cases but with less force. More important, I doubt that admitting presently inadmissible corroboration would reduce the number of erroneous convictions even under the most favorable circumstances since this change would have no effect at all on the evidence that is presented in cases without corroboration, the very cases where the danger of error is greatest. Corroborating information can improve a decision maker's ability to sort the accurate identifications from the inaccurate only if the sorting is done by someone who compares the evidence across different cases. Criminal juries, however, are ad hoc, single-case triers of fact.

The ability of juries to distinguish between accurate and inaccurate identifications might be helped by other procedures, in particular by providing them with information-through expert testimony or jury instructions or both-on situational factors that are known to affect eyewitness accuracy. These procedures may help, although the sum of their potential effects on jury accuracy is probably not great. Essentially, I doubt that much can be done to make juries more discriminating evaluators of identification evidence so long as we retain two fixed features of criminal trials: the use of one-time juries to determine facts and the exclusion from evidence of a broad range of information that is routinely available to the police and the prosecutor.

This brings me to the final method of reducing errors at trial: changing the standards that are used to judge evidence of identity. This could be accomplished by requiring admissible non-eyewitness corroboration of eyewitness testimony, by cautioning jurors in strong terms against relying on eyewitness identification evidence, or by imposing an extraordinarily high burden of proof on the prosecution, higher than proof beyond a 
reasonable doubt. The first of these changes, a requirement of corroboration, might improve the quality of evidence in some cases by encouraging the police to search for the necessary corroborating information. On the whole, however, these procedures would reduce the number of erroneous convictions in identification cases by brute force-by reducing the proportion of all convictions in such cases. The question is whether the benefit would be worth the cost.

How high would that cost be? A quantitative estimate would be mere guesswork, but the general nature of the trade is determined by two facts: (1) few defendants who are brought to trial have been misidentified, and (2) juries are not good at distinguishing them from the rest. As a result, any attempt to reduce the number of erroneous convictions by increasing the difficulty of proving guilt would cause a much larger increase in the number of erroneous acquittals. Moreover, the effects of this shift in standards would not be restricted to cases that are tried but would also change the basis for pretrial decisions to dismiss and the terms for plea bargaining. Reactions to such an asymmetrical trade are inevitably subjective. Some would argue that it simply embodies the venerable common-law principle (with which I agree) that it is better that many guilty people go free than that one innocent person be convicted. Nonetheless, I think it is a bad bargain -in part because erroneous convictions based on misidentifications are already rare, but primarily because the errors that do occur could be reduced more efficiently at the pretrial stages of litigation, where more information is available and where the existing sorting process is more effective.

Pretrial Investigation. Many problems that must be taken as given when a case comes to trial can be attacked directly in the pretrial investigation. In particular, the police can avoid suggestive identification procedures, and they can collect and preserve the physical evidence that is available at the scene of violent crimes. These two suggestions require nothing beyond workaday professional competence, but their general implementation would probably do more to reduce misidentifications in criminal cases than would any other set of policies. Correct procedures for obtaining pretrial identifications and for conducting on-the-scene investigations of violent crimes simply ought to be routine.

The next stage of investigation is more problematic. In theory the police could undertake an extensive investigation of every case in which the criminal's identity is in dispute-to test the suspect's alibi, to locate additional suspects, or both. In practice few police forces (if any) have the resources to do this for more than a small fraction of the violent crimes that come to their attention. Most police detectives work under constant pressure to close cases and to move on to new ones; they must, perforce, 
end the great majority of their investigations as soon as possible after a suspect has been identified. Unless there is an enormous and improbable increase in the corps of police detectives (or a comparable and more improbable decrease in the number of violent crimes) the police will still have to choose a small number of cases in which to invest scarce investigatory resources. Two guidelines might help them identify those cases in which the risk of error is greatest.

1. Spot Cases in Which There Are No Useful Corroboration of Eyewitness Identifications. The most important (and most ignored) group in this category involves cases in which the suspect was first located by his appearance and in which no confession or physical evidence of identity was obtained after the initial identification. Where there is some noneyewitness corroboration (whether admissible at trial or not), it should be scrutinized. Is it reliable? What does it establish? If the corroborating evidence is unreliable or proves little, the risk of error may be nearly as high as if there were none.

2. Spot Cases in Which the Eyewitness Identifications Themselves Are of Uncertain Origin. The common cases of this sort are those in which the identifications were made at suggestive confrontations that were initiated by the police, but similar problems will occasionally occur by accident. The difficulty in such cases is not that the eyewitnesses are necessarily wrong (often they turn out to be right) nor even that their choices are inevitably based on suggestion rather than on recollection. The problem is that there is no way to determine either the accuracy or the basis of the identifications from the eyewitnesses themselves, so any assessment of the risk of error must focus entirely on whatever non-eyewitness evidence of identity is available.

The Decision to Prosecute. The prosecutor, like the police investigator, must decide which few of the many cases she handles will receive extensive attention either from the police (at her request) or from her own investigators. A major goal of the prosecutor in making these choices should be the same as that of the police-to single out the high risk cases-and the same guidelines should apply, but the prosecutor, as a relative outsider to the initial investigation, may be in a better position than the police to evaluate the evidence objectively. In addition the prosecutor has the all-important power to decide which cases to pursue and which to drop, a power that the police generally lose once a suspect has been identified. ${ }^{132}$ The ability to distinguish weak identification evidence

132 The relative power of the police and of the prosecutors is illustrated by several misidentification cases in which prosecutors proceeded and obtained convictions despite serious doubts on the part of the police, who, in some instances, urged the prosecutors to wait or to drop the charges. See, for example, Borchard, supra note 50, at 46-50 (Benjamin 
from strong is critical, of course, in making these decisions, but there is also a second issue. What standard of certainty should the prosecutor demand as a condition for prosecution? The official norm is vague and minimal, ${ }^{133}$ and actual practice, not surprisingly, seems to vary widely.

The case of Father Bernard T. Pagano, ${ }^{134}$ one of the most publicized misidentifications in recent years, provides a useful illustration of the range of prosecutorial perspectives. Father Pagano was charged with a series of robberies in Delaware in 1979; after he was exonerated by the confession of the actual criminal he filed a civil law suit against the police, and in the course of the trial of that case three prosecutors testified on their views of the appropriateness of the decision to arrest and prosecute Father Pagano. ${ }^{135}$ (1) The former deputy attorney general who handled the case testified that he told the investigating police officer that there was "enough evidence-primarily identifications made by robbery witnesses who reviewed photographs of Pagano-to justify arresting him." (2) A second deputy attorney general testified that he told the same police officer that the evidence was not sufficient to arrest because of "the lack of physical evidence linking Pagano to the crime, the weakness of eyewitness identification as evidence in criminal cases, and the fact that Pagano, as a priest, was a person of note." (3) Finally, a third deputy attorney general testified that he "was never fully convinced of the guilt of Father Pagano" but "would let the evidence and the jury decide."

The first prosecutor and the second differed in their evaluations of the quality of the evidence. It is clear now that the first prosecutor was wrong-hindsight is always clear-but even at the time there were problems with the identification that were (or should have been) apparent. The second prosecutor mentioned some of these problems: the identification rested solely on eyewitness testimony, there was no physical evidence of identity, and Father Pagano's character made him an unlikely robbery suspect. In addition, Pagano became a suspect solely because of his appearance, and he had excellent alibis for some of the crimes with which he was charged, alibis that the prosecution never fully investigated. ${ }^{136}$

Collins), 328-29 (J. Anthony Barbera); Radin, supra note 52, at 112-13 (Edward Avila), 102-3 (John Shaw); Chicago Tribune, April 12, 1981, at 20, sec. 1. (Larry Smith).

133 See The Prosecution Function, in 1 Standards for Criminal Justice, Standard 3-3.9(b), $\S 3$, at 54 (2d ed. 1980); U.S. Dep't Justice, Principles of Federal Prosecution, Pt. B (2), 27 CrL 3277, 3278-79 (1980).

134 See, for example, N.Y. Times, August 24, 1979, at A12; Los Angeles Times, August 24, 1979, at 1; and Time, September 3, 1979 (Rev. Bernard Pagano).

135 Priest Recalls Mistaken Arrest as "Gentleman Bandit," Associated Press, March 22, 1984 (Rev. Bernard Pagano).

${ }^{136}$ San Francisco Sunday Examiner \& Chronicle, June 22, 1980, at 15A (Rev. Bernard Pagano). 
But however unfortunate the mistake of the first prosecutor (the one who was in charge of the Pagano case), the position of the third prosecutor-the one who would let the jury resolve his own doubts about guiltis far more troubling. There is every reason to believe that prosecutors, with more information at their disposal and more experience, are considerably better than juries at judging identification in criminal cases. There is certainly no reason to expect a jury to set things straight when the prosecutor remains in doubt. Perhaps the two best generalizations about jury deliberations in criminal cases are that the jury is very likely to reach a verdict and that it will probably convict. ${ }^{137}$ If, as I have argued, the infrequency of misidentifications by juries depends primarily on the pretrial sorting of identification cases, then a failure of prosecutors to make independent judgments of the defendants' guilt will sharply increase the number of erroneous convictions. ${ }^{138}$

The American Bar Association's Standards for Criminal Justice states that "the prosecutor's reasonable doubt that the accused is in fact guilty" is a factor "which the prosecutor may properly consider" in deciding whether to file charges. ${ }^{139}$ The only official commentary on this factor is a passing reference to "the obvious reasonable doubt test,", 140 a reference, presumably, to the obvious importance of this consideration and not to its clarity. I propose a different standard: a prosecutor should not proceed with a criminal case if, after reviewing all the available evidence of identity-evidence from the defense as well as the police, inadmissible evidence as well as admissible - the prosecutor has a reasonable doubt about the identity of the defendant as the criminal. In case of doubt, the prosecutor should attempt to obtain more evidence; if that cannot be done or does not help, charges should not be filed or, if already filed, should be dismissed. ${ }^{141}$

137 Harry Kalven \& Hans Zeisel, The American Jury $55-63$ (1966).
138 Unfortunately, the position of this prosecutor is not unique. For example, in another
recent misidentification case in which the suspect was located by his appearance and in
which there was no physical evidence of identity, the prosecutor said after the fact that she
had no regrets and no cause to apologize: "No case is perfect. . . When all three women
ndependently identified the same person and as the physical evidence developed and failed
to exclude [him] I had an obligation to proceed with the law and the protection of the
community. . . I really would have been remiss not to file charges. A prosecutor can't turn
down a case just because it's not the best in the world." San Francisco Sunday Examiner \&
Chronicle, November 9 , 1980, at $8 \mathrm{E}$ (Greg Taylor).
139 The Prosecution Function, supra note 133 (emphasis added).
140 Id., \& 3, at 56 .
141 A standard similar to but weaker than the one I propose is articulated in California District Attorneys Ass'n, Uniform Crime Changing Standards, § I.A. I (a), at 13 (1974) (prosecutor must be "satisfied" on the basis of "all pertinent data readily available" that defendant is guilty of crime charged), and $\S$ I.B.2(b), at 17-18 (prosecutor may consider inadmissible evidence in making charging decision). 
Needless to say, the "reasonableness" of a doubt is an issue on which people differ, and evaluations of the strength of a body of evidence are strongly influenced by the point of view from which it is seen. Prosecutors, by virtue of their role, tend to be concentrated at the proconviction ends of both of these spectrums: they are more likely than most people to interpret evidence as proof of criminal conduct, and they are more punitive and crime-control oriented than average. This professional orientation makes prosecutors an unlikely choice for the task of spotting innocent defendants. Eyewitness identification cases, however, may be an exception to this general rule for three reasons. First, prosecutors seem to be, on the whole, more skeptical of eyewitness identification evidence than juries, or at least more skeptical than juries are when the eyewitness evidence is presented to them by prosecutors. Second, jurors are less well situated than prosecutors to evaluate eyewitness evidence since they have less information and less experience. Third, the issue-erroneous conviction-is completely noncontroversial. No one wants to punish a misidentified defendant.

I have no illusion that a formal adoption of this proposed standard would transform prosecutorial practices. The trick would be to implement such a rule. Prosecutors would have to learn to be consistently critical in evaluating eyewitness identifications, to search for more evidence when necessary, and, most important, to dismiss cases when doubts persist. There would of course be a cost: some guilty defendants would go free. But this would be a cheaper and better method of reducing erroneous convictions than tightening the standards for decision at trial, for several reasons: (1) The proportion of exonerations in cases with guilty defendants would be smaller because the pretrial screening process is more efficient than the process of trial by jury. ${ }^{142}$ (2) More stringent standards for charging and prosecuting would improve overall accuracy by encouraging thorough investigations of close cases at the most productive time, early on. (3) If an error is made, an early dismissal will minimize the cost to the innocent defendant and maximize the chance of finding and prosecuting the actual criminal. (4) On the other hand, if the defendant is guilty, a pretrial dismissal, unlike an acquittal, is not a bar to a later prosecution if better evidence is discovered. ${ }^{143}$ And (5) mistakes, once made, seem to become increasingly difficult to correct the farther a case progresses through the criminal justice system. ${ }^{144}$

In a typical eyewitness identification trial the jury is asked to choose

\footnotetext{
142 For a more rigorous and detailed explanation of this point, see Appendix infra.

143 Crist v. Bretz, 437 U.S. 28 (1978).

144 See, for example, Rattner, supra note 55, at 5, 135-36.
} 
between two incompatible stories: the defendant and his witnesses say that he was elsewhere and could not have committed the crime, while the victim and the other prosecution witnesses say that they saw him do it and could not be mistaken. If each story is plausible on its own terms, there will be no direct way to resolve the conflict between them. In theory, the legal requirement of proof of guilt beyond a reasonable doubt should throw a close case to the defendant, but that is an unsatisfying way to decide a case; jurors would rather figure out what happened, and that requires choosing one story over the other. In effect, the jurors must take sides, a choice that almost seems designed to maximize the temptation to rely on the judgment of the prosecutor, the public servant, the law enforcement professional who is responsible for the case. Indeed the fact that juries convict on the basis of uncorroborated eyewitness identifications may not demonstrate that they overvalue eyewitness testimony in the abstract but rather that they trust prosecutors. ${ }^{145}$ To the extent that this is so, the problem of erroneous convictions in identification cases is only an example, the most important example, of a more general phenomenon.

The failure of a prosecutor to reach an independent and informed judgment on the defendant's guilt is particularly unfortunate in view of the fact that many jurors assume that if a criminal case has come to trial the prosecutor has done just that. Jurors, of course, are not supposed to consider the charges against a criminal defendant as evidence of guilt. They are instructed that the prosecution has the burden of proving the defendant's guilt beyond a reasonable doubt, and they are told that the defendant is "presumed to be innocent" until such proof is produced-a "presumption" that is, analytically, no more than a reiteration of the allocation of burden of proof, but that conveys a special warning to criminal jurors "to consider, in the material for their belief, nothing but the evidence, i.e., no surmises based on the situation of the accused." 146 The reason for this special warning is the fear that jurors are prone to ignore this restriction, ${ }^{147}$ and, warning notwithstanding, there is a lot of anec-

\footnotetext{
145 This is an empirical question and, perhaps, a testable one. It might be possible, for example, to ask two groups of experimental subjects to act the role of jurors and to compare their judgments of the same eyewitness identification evidence in two simulated contexts, a criminal prosecution and a civil lawsuit. If the subject-jurors were given appropriate instructions on the burdens of proof, this would be a severe test of the hypothesis that convictions in criminal eyewitness identification cases are due more to the nature of the proceeding than to the nature of the evidence since the formal rules of proof permit greater reliance on uncertain evidence in the civil context.

1469 John Henry Wigmore on Evidence, $\S 2511$, at 530 (Chadbourn rev. ed. 1981).

147 Id. at 530-32.
} 
dotal evidence that they often do. For example, some criminal trial lawyers report that jurors in close eyewitness identification cases have told them that they voted to convict because they realized that the prosecutor must have had other more convincing evidence of guilt, evidence that the jurors, for some unknown reason, were not allowed to hear. ${ }^{148}$ This is not a bad guess-prosecutors often do have such evidence-but when it is wrong (and jurors have no way of knowing) it is a dangerous basis for a decision.

\section{Conclusion}

The Supreme Court probably overstated the case when it said in Wade that "the trial which might determine the accused's fate may well not be that in the courtroom but that at the [initial] pretrial confrontation" with the eyewitness. ${ }^{149}$ It is no doubt true that courtroom trials are a poor remedy for identification errors, but the pretrial process of identification usually includes quite a bit more than the confrontation with the eyewitness, and it is the overall accuracy of this process that makes erroneous convictions rare.

Rare, however, does not mean unimportant. Airline crashes are exceedingly rare, yet we go to great lengths to maintain that fact and to make them even less likely. I have argued that the best way to reduce the number of convictions based on misidentifications is to improve the quality of pretrial determinations of identity and to tighten the standards for prosecution in cases in which identity is in dispute. Some reforms in trial procedure might be useful, but primarily those designed to force the police and prosecutors to improve their investigations rather than those aimed at improving the accuracy of courtroom judgments. The major impetus for change, however, must come from the law enforcement community itself.

This conclusion leaves me uneasy. Like most American lawyers of my age and background, I was brought up to see the criminal justice system from a due process perspective. It cuts against the grain to argue that prosecutors and police officers should have primary responsibility for protecting innocent defendants. But reality, it seems, is at odds with the due process heritage, at least in this context. In fact, prosecutors and police officers already fill this protective function to some extent, and they have more power to make identifications safe than any other actors in the system. How they will use that power is another matter.

\footnotetext{
148 Personal communication from Professor Barbara Babcock, former director of the Public Defender Service for the District of Columbia, February 1985.

149 Wade v. United States, 388 U.S. 218, 235 (1967).
} 


\section{APPENDIX}

This Appendix is offered for those readers who may be interested in a more systematic development of some of the points made in the text.

Figure A1 represents a hypothetical flow chart of the disposition of 1,000 felony cases in which the only factual issue is the identity of the criminal and in which the only admissible evidence of identity comes from eyewitness identifications. While the numbers in Figure A1 are merely illustrative, the relative proportions of convictions, acquittals, guilty pleas, and dismissals would not be surprising in an American jurisdiction (keeping in mind that some of the convictions, and many of the guilty pleas, will be for misdemeanors). On the other hand, the true proportions of defendants who are correctly identified and mistakenly identified are, of course, always unknown.

In Figure A1 the flow of these cases is divided into six "stages." These stages are not necessarily chronological, and a complete picture would include more of them, but this simplified version is sufficient for present purposes. At stage 1, I assume that only one defendant in twenty $(50 / 1,000)$ is wrongfully charged. This assumption is debatable (the actual proportion may be higher or lower), but the general principle is not, I think, in dispute: when a person is charged with a felony, even on the basis of eyewitness identification evidence, it is very likely that he is guilty.

At stage 2, I assume that 14 percent of the cases are dismissed before trial (140/ $1,000)$, including 80 percent of those cases with misidentified defendants $(40 / 50)$. The 80 percent figure is higher than the data here suggest-about 60 percent of the reported post-Wade misidentifications that I located were detected and dismissed before trial-but cases that were dismissed early are disproportionately underreported in these data since the freeing of a convict from prison is likely to be a bigger news item than the dismissal of charges against a suspect who is free on bail. On closer inspection this group of 140 dismissals decomposes into two separate groups. On the one hand (stage $2 \mathrm{~A}$ ), there are those cases that the prosecutor dismisses for misidentification on the basis (I assume) of concrete and convincing evidence of innocence. For the sake of simplicity I also assume that evidence of that sort is never produced when the defendant is in fact guilty. On the other hand (stage 2B), the prosecutor also dismisses a larger number of cases for a host of reasons unrelated to doubts about identity, typically because of the lack of credible admissible evidence of guilt. In most of these cases the defendants are in fact guilty, but in a few, fortuitously, they are innocent.

At stage 3, I assume that 66 percent of all defendants plead guilty $(660 / 1,000)$ but that none of those who do so are in fact innocent. The data reported in this article strongly suggest that misidentified defendants very rarely plead guilty, but the assumption here is a simplification and, as a result, an overstatement.

As a result of these dismissals and guilty pleas, one-fifth of all the cases (200/ $1,000)$ are left to go on to jury trial (stage 4). In 5 percent of those cases the defendants have been misidentified (10/200). Of these trials, I assume (stage 5) that 20 percent $(40 / 200)$ result in acquittals and (stage 6) that 80 percent $(160 / 200)$ result in convictions. (For simplicity I assume that there are no hung juries and no bench trials.) I also assume that half of the misidentified defendants $(5 / 10)$ are acquitted compared to 18 percent of those who were correctly identified $(35 / 190)$. (This is probably an overly generous estimate of the power of juries to distinguish innocence from guilt in identification cases, especially since those cases with 
(2A)

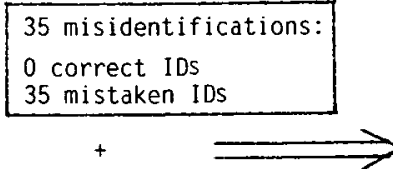

(2B)

105 other dismissals:
100 correct IDs
5 mistaken IDs

(1)

1000 felonies:

950 correct IDS 50 mistaken IDs

(2)

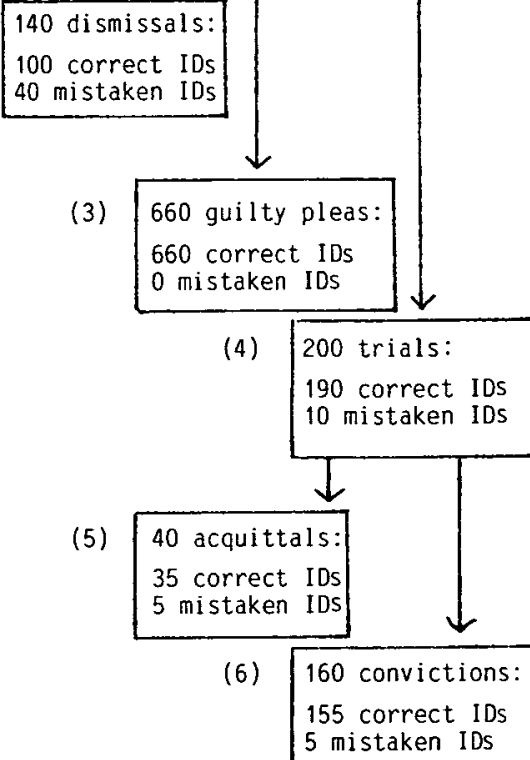

FIgURE A1.-Hypothetical flow chart for felony cases based on eyewitness identifications. (i) pr(misidentification) $\mid$ (conviction or guilty plea) $=.006 ;($ ii) pr(conviction or guilty plea) $\mid($ charge and correct ID) $=.86$; (iii) pr(conviction or guilty plea) $\mid$ (charge and misidentification) $=.1$.

guilty defendants that go to trial are likely to be the ones with weak evidence of identity. For present purposes, this is a conservative assumption.) As a result, at the final stage (stage 6) 16 percent of all cases end in jury convictions $(160 / 1,000)$; but only 3 percent of these convictions $(5 / 160)$ involve innocent defendants.

At the bottom of Figure Al some of the consequences of these assumptions are summarized in three equations (using statistical notation). (i) The probability that a defendant has been misidentified, given that he was convicted or pleaded guilty, is 0.006 , or 0.6 percent. (ii) The probability of a conviction or a guilty plea, given that a defendant has been charged and is in fact guilty, is 0.86 , or 86 percent. (iii) The probability of a conviction or a guilty plea, given that a defendant has been charged but has been misidentified, is 0.1 , or 10 percent.

This flow chart illustrates the high level of accuracy on the part of prosecutors and police officers that my hypothesis assumes: 95 percent of the charges in this hypothetical set of identification cases are true (at least as to identity), and 80 percent of the remaining errors are weeded out before trial. This may seem unreal- 
istic, but $I$ do not think so, in part because the simplified nature of this chart conceals some of the actual process of winnowing, a process that has more potential points of selection. The chart posits the initial distribution of charges as an a priori fact; in practice, a decision to charge in a close case may depend on the ability of the police to satisfy the prosecutor's request for further investigation. Similarly, the option to dismiss in a case in which the defendant has in fact been misidentified is likely to resurface repeatedly as more evidence is discovered. In any event, if the police and prosecutors do worse than I have assumed (or, perhaps more accurately, when and where they do worse), the proportion of erroneous convictions will be higher-unless, somehow, juries do even better than my generous assumption.

This chart can also be used to illustrate the consequences of different methods of attempting to eliminate the erroneous convictions that do occur. Assume that the goal is to reduce the final number of erroneous convictions from five to two. First, the prosecutor could accomplish this by increasing the number of dismissals at stage $2 \mathrm{~A}$, but, since all the clear-cut cases of misidentification have already been dismissed, this cannot be done without also freeing some guilty defendants. Since (by assumption) half of the misidentified defendants who pass this point are ultimately acquitted anyway, to eliminate three additional convictions of innocents the prosecutor will have to dismiss charges against six such defendants. Assuming that the prosecutor misses two-thirds of the time in this new task of dismissing questionable cases, the cost of saving three additional erroneous convictions will be twelve additional erroneous dismissals. This is a high proportion of errors but a small number in the overall scheme, and there is no reason to suppose that these dismissals will affect the dispositions of any other cases. Assuming (conservatively) that all twelve of these guilty defendants would otherwise have been convicted, the ultimate effect would be to reduce the probability of a guilty plea or conviction, given that a defendant has been charged and was correctly identified, from 0.86 to 0.85 .

Second, the courts could accomplish this change by increasing the number of jury acquittals at stage 5 , perhaps by imposing an extraordinary burden of proof on the prosecution. As things stand, juries acquit seven correctly identified defendants for every misidentified one. If this remained unchanged, twenty-one guilty defendants would have to be acquitted to reduce the number of erroneous convictions by three. Unfortunately, however, this ratio would be likely to get even worse. For one thing, the proportion of misidentified defendants in the pool of trials that now end in convictions is smaller than the comparable proportion for all trials, one in thirty-two as opposed to one in twenty, so the misidentified defendants who remain among those convicted at trial will be harder to locate than those who were already culled out. In addition, the reason that the ratio of acquittals of guilty defendants to acquittals of innocent defendants was as low as seven to one in the initial condition was the (generous) assumption that juries would be more likely to acquit the innocent because the evidence of identity in their cases would look less convincing. But, having already removed the least guilty looking cases in both categories, the next level of distinctions will be harder to make, the choices will involve a higher component of chance, and the relative advantage conferred by actual innocence will be reduced. If juries acquit additional misidentified defendants at the same rate as additional guilty defendants (not an unreasonable possibility), the cost of each additional correct acquittal would be thirty-two additional erroneous acquittals. Assuming a more optimistic state of 
affairs, the ratio might be as low as fifteen to one; this means that it would take forty-five additional acquittals of guilty defendants to secure the acquittal of three additional misidentified defendants.

Forty-five mistaken acquittals is certainly worse than the twelve mistaken dismissals-especially since acquittals are final adjudications and dismissals may not be-but that is only a part of the story. The effect of this would be to raise the overall proportion of jury acquittals from 20 percent to 44 percent, and that would induce many of the defendants who would have pled guilty to go to trial. If, for example, 150 additional correctly identified defendants choose to go to trial, the result might be yet another forty-five erroneous acquittals. (This last calculation is based on the assumption that the evidence against those defendants who previously would have pled guilty but who now go to trial is more convincing than is the evidence against those who originally went to trial, so the acquittal rate for these new trials might be as low as 30 percent rather than the 44 percent acquittal rate for the original group of trials of guilty defendants.) The bottom line is that while the prosecutorial reform would cost twelve erroneous dismissals, the trial reform would cost ninety erroneous acquittals; and while the former change would reduce the probability that a correctly identified defendant would be convicted by plea or at trial from 0.86 to 0.85 , the latter change would reduce that probability to 0.76 . 